\title{
Wage differences in the hospitality sector ${ }^{1}$
}

\begin{abstract}
The article examines the origin of differences between wages in the hospitality sector and the rest of the private sector in Spain. The evidence obtained for the 2002-2010 period shows that the wage disadvantage of hospitality presents an increasing profile along the wage distribution so that it is particularly relevant for those earning comparatively higher salaries. In contrast with other low-wage sectors, lower wages in hospitality are explained almost entirely by the specific characteristics of its workers and jobs (particularly their lower educational qualifications and their higher presence in low-skilled occupations), and not by the existence of lower rewards to those characteristics. Highly qualified individuals are however an exception since they suffer a wage penalty for working in the sector. Furthermore the analysis shows that pay inequality is substantially lower in the hospitality sector and that it is not due to the relative characteristics of its workers and jobs.
\end{abstract}

Key terms: Hospitality; decomposition; wages; wage differences.

JEL codes: J16, J31, J71, L83

\section{Introduction}

Tourism is a particularly relevant economic sector in that it makes a considerable contribution to aspects such as economic growth (Brida et al., 2014) or the capacity for creating employment, especially between population groups who usually experience greater difficulty in accessing the job market, such as women, young people and immigrants (Liu and Wall, 2005). This is particularly marked in the case of Spain, where both the contribution of tourism to GDP and the weight of this sector in total employment double those of other OECD countries. Thus in 2012 tourism accounted for 10.8\% of GDP and 11.8\% of employment ( 2 million persons), and international arrivals in that year consolidated Spain as the fourth largest destination worldwide and the second largest in terms of receipts (OECD, 2014). It is also noticeable that in Spain some tourism sub-sectors such as hospitality have been among the best performers in terms of employment during the Great Recession, as the dearth of jobs that ensued following the start of the economic crisis has had considerably less effect on this sector than on the economy overall (Turespaña, several years data).

However, the available literature has amply demonstrated the fact that employment in tourism is generally characterised by many negative features. These negative aspects have persisted over time and are observable in all economies (see, for example, Ladkin, 2011, or Gerogiannis et al., 2012 for the specific case of European Union). Thus, tourism jobs are characterised by long

\footnotetext{
1 This work was supported by the Spanish Ministry of Economy and Competitiveness under Grants CSO2011-29943C03-02 and CSO2014-55780-C3-2-P (National R\&D\&I Plan).
} 
unsociable hours and unfavourable pay and working conditions, poor wages, shifts, gender discrimination and narrow job functions, as well as low skilled work and lack of training opportunities (Ladkin, 2011). In this regard, in the particular case of Spain, the hospitality sector registers a considerably greater proportion of part-time, temporary and seasonal work compared to other sectors of the economy; in addition to lower levels of formal education and in-company training, and increased unsocial working time and stress levels (Sanz, 2012).

The analyses of the characteristics of jobs in tourism usually highlight, in a manner consistent with the characteristics described previously, the fact that in the tourism sector in general and particularly in the hospitality sector, average wages are lower (see Riley et al., 2002, Muñoz-Bullón, 2009 or Santos and Varejão, 2007). Despite the importance of this issue there is a lack of detailed studies providing adequate knowledge on the origin of the differences between the average wages of those working in tourism and in the rest of economic sectors. In other words, although the existence of lower wages is well documented no attempt has been made to systematically assess the extent to which this phenomenon derives from the specific characteristics of both tourism workers and the jobs they occupy (a composition effect) or whether it is due to the fact that those characteristics are less rewarded in the sector, compared to the rest of the economy or to other low-wage sectors (a return effect). This lack of studies also applies to the analysis of both the potentially heterogeneous behaviour along the wage distribution (a question over which only fragmented evidence exists at the moment) and the sector's relative degree of wage inequality. The existence of these gaps in the literature is consistent with the fact that the analysis of tourism labour has still not been well developed and the contributions in this field in general are still scarce (see in this respect Riley et al., 2002, Xiao \& Smith, 2006 and Ladkin, 2011), with most of these focusing on rather specific questions such as gender discrimination or the returns to education in the sector.

This article contributes to the literature by examining the origin of the differences in wage structures between the hospitality sector and the rest of the economy in Spain, a country in which, as indicated, the tourism sector carries particular weight. To this end micro-data from the Structure of Earnings Surveys for 2002, 2006 and 2010, and two econometric decomposition methodologies were used, making it possible to contrast both the reasons for differences in average wages (Oaxaca-Blinder decomposition) and those existing in levels of inequality and in wage differences throughout the wage distribution (Fortin-Lemieux-Firpo decomposition). Both econometric techniques share the advantage that they permit the individual impact of the different explanatory variables for the wage differentials between sectors to be quantified, thus overall they provide ample empirical evidence on their origin. Moreover the exploitation of data from three different 
years allows assessing the extent to which the results obtained are stable or register variations across time associated with the economic cycle.

The article is organised as follows. The next section reviews the literature that has examined wage aspects in the tourism sector. The third and fourth sections describe the database and the econometric decomposition methodologies employed. The fifth section shows and discusses the main findings of the empirical analysis. Finally, the last section provides the main conclusions of the study.

\section{Wage aspects in the tourism sector}

Many works that analyse wage-setting mechanisms in the tourism sector take as a reference the human capital theory, so that one of the variables of interest of a first large group of articles has been, precisely, education and its relation to wages. The evidence available indicates that education returns are systematically lower in tourism than in other sectors (Lillo-Bañuls and Ramón-Rodríguez, 2005; Marchante et al., 2005; Fernández et al., 2009; Lillo-Bañuls and CasadoDíaz, 2012 and 2015), and that the hospitality sub-sector is, moreover, relatively penalised in relation to the tourism sector overall (Lillo-Bañuls and Casado-Díaz, 2010). Some authors analyse in turn specific aspects of this relation such as the existence of sheepskin effects in educational returns in the Norwegian tourism industry (Thrane, 2010) or the influence of social capital on the wages of Portuguese hotel managers (Pestana and Santos, 2009). Similarly, in the case of Spain it has been found that the pattern of lower returns to education observed for tourism overall is systematically reproduced for almost all occupations, although the differences are heterogeneous in their magnitude (García-Pozo et al., 2011). Previous research has also found significant regional differences between the disparities of wage returns between hospitality and the rest of the private service sector (Campos-Soria et al., 2011a and García-Pozo et al., 2012). In any case, it should be underlined that the magnitude of differences between tourism activities and other sectors of the economy, in terms of wage returns to education, exhibits some differences based on countries, the period of time or the method of estimation considered.

A second set of studies has addressed the differences associated with gender, noting that, as with the rest of the economy, women's wages are systematically lower both in the tourism sector and in the hospitality subsector (Santos and Varejão, 2007; Thrane, 2008; Muñoz-Bullón, 2009; García-Pozo et al., 2012). With respect to the origin of the differences found, it has been confirmed, in turn, that the disadvantage suffered by women compared to men with the same productive characteristics would appear to be on average lower in the tourism sector than in the economy overall (Lee and Kang, 1998; Santos and Varejão, 2007; Fernández et al., 2009; Campos- 
Soria et al, 2011a). ${ }^{2}$ Thus Santos and Varejão (2007) using the Oaxaca-Blinder technique confirm that around half of the wage differences between men and women in Portugal are due to differences in attributes (whereas the rest have their origin in the lower remuneration of the same characteristics, which could be due to discriminatory treatment), as well as the fact that the coefficient of discrimination obtained with this technique in the tourism sector is substantially lower than that of the rest of the economy. This is also observed in the case of Spain where the unexplained component obtained using the Oaxaca-Blinder technique is substantially lower in the tourism sector overall and the hospitality subsector than in the rest of the economy (MuñozBullón, 2009 and Fernández et al., 2009, respectively), although it also shows considerable differences between regions (García-Pozo et al, 2012). In this vein, it is also important to highlight that this evidence is generally compatible with the fact that employment of women in the tourism sector is strongly segregated both horizontally and vertically (Sinclair, 1997; Sinclair and Stabler, 1997; Campos-Soria et al., 2011b) and that as a result they tend to be concentrated in low-wage occupations and sectors. ${ }^{3}$

In many of the previous studies the mere descriptive analyses preceding the econometric estimates systematically show that average wages of employees working in tourism are comparatively low (e.g. Santos and Varejão, 2007; Muñoz-Bullón, 2009; Lillo-Bañuls and CasadoDíaz, 2012), and that the hospitality sub-sector is particularly affected by this fact (Lee and Kang, 1998; Thrane, 2008). ${ }^{4}$ Several crucial aspects have however been largely neglected by previous literature: the origin of such wage differences; whether they are similar along the wage distribution and can be explained by the same variables; and the relative degree of wage inequality in the sector and how it can be explained. Two previous articles deserve attention in this context since they provided some fragmentary evidence on these issues. The first is the study conducted by Sturman (2001) examining wage differences between jobs with comparable training requirements in the hospitality sector and the rest of the economy are. The results, which are therefore based on the analysis of only one of the possible variables explaining the differences (qualifications), show that the hospitality industry in the U.S. pays approximately the same for jobs with few training requirements but comparatively less for jobs which are reasonably complex or require higher levels of qualification. The second study, carried out by Lee and Kang (1998), focused on the relative

\footnotetext{
2 According to Skalpe (2007) however, the opposite occurs with female CEOs.

3 In some countries such as Portugal or Spain, it may also happen that as tourism is a low pay sector, laws on minimum wages could in practice be assumed to be an effective protection for women who are low wage earners in that sector (Santos and Varejão, 2007 and Muñoz-Bullón, 2009).

4 Riley et al. (2002) and Riley and Szivas (2003) propose a conceptual framework for analysing wage-setting mechanisms in tourism, a sector in which according to the authors, a "tolerance of low pay" is observed and in which what are known as "deflationary pressures on the level of pay" predominate, associated with factors such as recruiting in large labour markets; high levels of staff turnover and the propensity to have weak internal labour markets due to easily acquired, transferable skills.
} 
wage inequality in the hospitality sector of the South Korean economy and highlighted, on the basis of various indicators, that the levels of wage inequality were lower in the hospitality sector than in the service industry. Findings of both articles point at the presence of differences between tourism and the rest of the economy in aspects of wage structure differing from average wages, as are wage differences throughout the wage distribution or the levels of wage inequality, issues which are thoroughly analysed in the rest of the article.

\section{Data}

The source of information where the micro-data used in the research come from is the Structure of Earnings Survey (in Spanish Encuesta de Estructura Salarial, hereinafter the EES). The EES is a survey drawn up by the Spanish National Statistical Institute (Instituto Nacional de Estadística), according to a harmonised methodology for all countries in the European Union, which is designed to obtain comparable information between countries on the characteristics of wage distributions. The survey covers employees who were registered at the Social Security during the month of October in the year of reference and the design of which corresponds to a two-stage sample of wage earners within firms. The study includes observations for several wage earners in each firm and, therefore, one of its most characteristic features is that it includes matched employer-employee micro-data, a type of data which overall has had an extremely significant impact on the analysis of wage determination (Hamermesh, 2008 and Abowd and Kramarz, 1999).

The EES consists of independent cross-sections which are drawn up usually every four years. There are currently four available waves, corresponding to the years 1995, 2002, 2006 and 2010. Over time, these waves have increased both in survey coverage (in the 2002 wave for the first time non-market service sectors, such as education, health and other social activities, were included; in that of 2006 establishments with less than 10 workers entered the survey and in that of 2010 the sector of activity corresponding to the Public administration and defence and compulsory Social Security was also included) as well as the information they contain on workers' characteristics (the 2002 wave included for the first time information on the nationality of individuals and whether they carry out supervisory tasks). For this reason the analysis developed in the research is confined to the waves of 2002, 2006 and 2010 of the EES, as these provide a practically exhaustive coverage of the private sector in the Spanish economy (namely the 2010 wave of the survey covers establishments of any size whose economic activity is framed in sections $\mathrm{B}$ to $\mathrm{S}$ of the CNAE-09 sector classification), facilitating comparison of hospitality sector ${ }^{5}$ with the

\footnotetext{
${ }^{5}$ As is the case in much of the specialised literature, tourism-related sectors cannot be consistently disaggregated from other sectors due to data source limitations, and therefore the analysis focuses on the hospitality sector (that accounts for almost 70\% of tourism employment in Spain; Turespaña, 2014).
} 
rest of the private sector. It must be noted that although in the 2010 wave a new sector classification is used in relation to previous EES waves (CNAE-09 instead of CNAE-93), identification of the hospitality sector is unequivocal in all these (corresponding to section I in CNAE-09 and section $\mathrm{H}$ according to CNAE-93).

The source of data used provides very detailed information on wages and the characteristics of workers (sex, age, education and nationality); of their jobs (occupation, tenure, type of contract, type of working day and performance of supervisory tasks) and firms (sector, size, type of collective agreement and region). Wage information includes the different components that make up the wage and covers different temporal references including wage components of a monthly and annual nature. For the purposes of this research, the wage concept used is wage per hour, calculated on the basis of the monthly wage corresponding to October, divided by the number of hours worked in said period. ${ }^{6}$ Wages are expressed in gross terms and their calculation incorporates any type of payment by firms, including commissions, bonuses for nigh shifts and weekends, as well as overtime payments.

In respect of the empirical analysis, those observations with unavailable information on the main variables of interest, or corresponding to individuals younger than 16 or older than 65 years of age or with hourly wages lower than one euro or higher than two hundred euros were filtered. In addition, in order to use a homogeneous sector coverage between the EES waves, the observations corresponding to section O of the CNAE-2009 classification (Public Authority and defence; Obligatory Social Security) were eliminated in the wave of 2010. The final samples amount to 122,432 observations for 2002, 140,241 for 2006 and 164,648 for 2010, of which 8,659, 9,470 and 5,307 corresponded to the hospitality sector, respectively. Descriptive statistics of these samples are shown in table A.1 of the appendix.

\section{Methodology}

In the empirical analysis two econometric methodologies are used in order to break down the wage differences between the hospitality sector and the rest of the Spanish economy. The first is the Oaxaca-Blinder methodology (Oaxaca, 1973 and Blinder, 1973), which permits a detailed decomposition of the differential between the average wage of individuals of both groups. The second is the methodology recently proposed by Fortin, Lemieux and Firpo (2011) which provides

\footnotetext{
6 The October wage was taken as a reference given that having worked during that month was the prerequisite for defining the population scope of the survey, following the framework established by the European Union. The total number of hours worked during the month was calculated as a normal working weekday multiplied by 4.35 plus the number of overtime hours worked. The most obvious alternative to the use of the wage hour is the use of their annual equivalents. This last option was ruled out because the annual figure which can be obtained on the number of hours worked based on the survey refers to the working day agreed on for the year between the employer and employee, and not on the number of hours effectively worked, which excludes overtime hours.
} 
a detailed decomposition of the wage differences throughout the wage distribution. Both techniques are described below.

\subsection{Oaxaca-Blinder decomposition}

The Oaxaca-Blinder technique is based on the separate estimation for each group of a semi-logarithmic Mincerian wage equation with the following form:

$$
w_{i}=X_{i} \beta+\varepsilon_{i}
$$

Wherein $w_{i}$ corresponds to the logarithm of the gross wage per hour of the worker $i ; X_{i}$ is a vector of individual explanatory variables plus a constant term; $\beta$ is a parameters vector and $\varepsilon_{i}$ is a random error term.

Having estimated the wage structure with the overall sample of hospitality sector individuals and those of the rest of the economy, and using the wage structure estimated jointly for individuals of both groups as the wage structure of reference in the decomposition, ${ }^{7}$ based on the properties of the ordinary least square estimator, the difference in average wages between the hospitality industry and the rest of the economy $(\Delta)$ may be broken down as follows:

$$
\Delta=\left(\bar{W}^{r}-\bar{W}^{b}\right)=\left(\bar{X}^{r}-\bar{X}^{b}\right) \hat{\beta}^{*}+\left\{\bar{X}^{r}\left(\hat{\beta}^{b}-\hat{\beta}^{*}\right)+\bar{X}^{b}\left(\hat{\beta}^{*}-\hat{\beta}^{r}\right)\right\}
$$

Wherein $\bar{W}^{r}$ and $\bar{W}^{h}$ are the average wages of the rest of the economy and hospitality sector; $\bar{X}^{r}$ and $\bar{X}^{h}$ are the average observed characteristics of individuals of both groups and $\hat{\beta}^{r}$, $\hat{\beta}^{h}$ and $\hat{\beta}^{*}$ are the estimated coefficients following regression of wages on the set of explanatory variables for the rest of the economy, hospitality industry and the pool of both sectors respectively.

The first component of the right-hand side of the equation (2) represents the effect on the average wage differential arising from differences in characteristics (or 'explained' component) whereas the second corresponds to the return of said characteristics (the effect of the coefficients or 'unexplained' component). It is important to point out that this procedure enables a detailed breakdown to be obtained, distinguishing, as a result, the contribution of each individual explanatory variable to the differential to be explained.

\subsection{Fortin-Lemieux-Firpo decomposition}

\footnotetext{
7 Thus, we follow Oaxaca and Ransom (1994) and Neumark's (1988) recommendation to use as the reference wage structure in the breakdown that corresponding to the pool of individuals of both groups. Moreover, a dummy variable relating to the group belonging to each observation was included in the estimation, given that its omission could lead to bias in the breakdown as overvaluation of the characteristics component and the corresponding underestimation of the returns component, caused by the omission of specific intercepts for each group (Elder et al., 2010).
} 
Fortin, Lemieux and Firpo (2011) have recently proposed a technique which enables the development of the empirical decompositions of differences between two distributions of a variable. In the end, this technique provides a breakdown of the differences between distributions in the value of any distributional statistic, as the value of a quantile or an inequality index, based on the differences in the endowments of characteristics and in its returns respectively. This is a procedure which has considerable advantages compared to other techniques previously proposed in literature which also permit the development of empirical breakdowns of differences between distributions based on construction of counterfactual distributions (DiNardo, Fortin and Lemieux, 1996, Juhn, Murphy and Pierce, 1993, Machado and Mata, 2005 and Melly, 2006). Thus, whereas the latter techniques consist of aggregated decompositions which, aside from partial exceptions, provide exclusively the separate effects of the characteristics and returns components, Fortin, Lemieux and Firpo's methodology provides a detailed decomposition which additionally makes it possible to ascertain the individual contribution of each explanatory variable considered in the analysis.

This methodology is based on the estimation of a regression in which the independent variable (the wage) is substituted by a transformation of the same, the recentered influence function; hereinafter the RIF) so that subsequently a standard Oaxaca-Blinder decomposition can be developed for any distributional statistic based on the regression results (for further details, see Fortin, Lemieux and Firpo, 2011). The decomposition takes the following form: ${ }^{8}$

$$
\Delta_{Q_{\theta}}=\left(\bar{X}^{r}-\bar{X}^{h}\right) \hat{\gamma}_{Q_{\theta}}^{*}+\left\{\bar{X}^{r}\left(\hat{\gamma}_{Q_{\theta}}^{h}-\hat{\gamma}_{Q_{\theta}}^{*}\right)+\bar{X}^{h}\left(\hat{\gamma}_{Q_{\theta}}^{*}-\hat{\gamma}_{Q_{\theta}}^{r}\right)\right\}
$$

Wherein $\Delta_{Q_{\theta}}$ is the difference in the quantile $Q_{\theta}$ (or, as has been indicated, in any other distributional statistic, as the Gini index) of the wage distributions of the rest of the economy and the hospitality industry, respectively; $\bar{X}^{r}$ and $\bar{X}^{h}$ are the average observed characteristics for the rest of the economy and the hospitality sector and $\hat{\gamma}_{Q_{\theta}}^{r}, \hat{\gamma}_{Q_{\theta}}^{h}$ and $\hat{\gamma}_{Q_{\theta}}^{*}$ are the estimated coefficients following regression of the RIF variable of the quantile $Q_{\theta}$ on the group of explanatory variables for the remainder of the economy, hospitality sector and the pool of both groups respectively. The first component of the right-hand side of the equation represents the effect on the differential between distributions caused by differences in characteristics (or 'explained' component) whereas the second corresponds to the effect of the coefficients (or 'unexplained' component). As has been previously indicated, the results of the breakdown show the contribution of each individual explanatory factor.

\footnotetext{
8 When developing the decomposition, the same methodological decisions than with the Oaxaca-Blinder decomposition have been adopted in aspects such as the reference wage structure or the normalisation of dummy variables.
} 


\section{Results}

\subsection{Descriptive evidence}

Figures 1 and 2 and tables 1 and 2 contain descriptive evidence for the period examined of the hourly wage distribution (expressed in logarithms) and the corresponding levels of inequality (measured on the basis of the Gini index) separately for the hospitality sector and the rest of the private sector of the Spanish economy. This evidence confirms that, irrespective of the year considered, the wage distribution in hospitality sector differs significantly from that of the rest of the economy, given that in that sector there is a greater presence of individuals earning comparatively low wages and a lower wage inequality. The wage disadvantage for hospitality workers is in fact extremely significant as it is on average between 0.207 and 0.232 logarithmic points, with slight countercyclical variations (table 1 and figure 2). ${ }^{9}$ Nevertheless, this disadvantage is not homogeneous as it clearly has a growing profile throughout the wage distribution, being comparatively reduced for individuals with lower wage levels but particularly high for those with higher wages (table 1 and figure 2). Similarly, notable differences were found in the levels of wage inequality as these are systematically lower in the hospitality sector than in the rest of the private sector (table 2) ${ }^{10}$, in line with Lee and Kang's results (1998).

In turn the A.1 table of the appendix contains descriptive statistics for the EES waves used in the empirical analysis. These permit confirmation of the presence of significant differences in the relative characteristics of hospitality employees and the rest of employees in the Spanish economy. Thus, without being exhaustive, in relation to the rest of the economy, on average, workers in the hospitality industry are to a much greater degree women and immigrants, and among them there is a much greater presence of those who have part-time contracts and occupations associated with reduced levels of qualification. They also have lower levels of study and seniority in the company. In addition, they are characterised by having a greater presence in posts with supervisory responsibilities and slightly greater levels of experience. Finally, they also work to a greater degree in smaller establishments covered by sectoral agreements and located in certain regions with a considerable tourism industry such as the Canaries or the Balearics. Therefore, the relative characteristics of hospitality employees are associated in general with

\footnotetext{
${ }^{9}$ It is noticeable that the economic crisis has not had an apparent sizeable effect on this aspect: between 2006 and 2010 only a slight increase in the hospitality wage disadvantage (which remains at quite similar levels along the wage distribution) is observable (table 1 and figure 2).

${ }^{10}$ Also in this case only a slight change is observable between 2006 and 2010: the Gini index decreased from 0.101 to 0.088 .
} 
comparatively low wages, ${ }^{11}$ although in certain cases the opposite occurs as, for example, they exhibit have more experience and work in a slightly greater proportion with supervisory responsibilities, circumstances associated with higher wages.

In short, the foregoing evidence confirms that there are very relevant differences between the hospitality sector and the rest of the economy in wage distributions and in the characteristics of their employees, jobs and companies. In the rest of the section econometric methodologies are applied, making it possible to examine the extent to which the differences noted in the wage structure of the hospitality industry and the rest of the economy comply with the differences in the endowments of productive characteristics between both sections of the economy. Insofar as the wage differences noted are not restricted to differences in average wages, methodologies are used which permit a detailed breakdown of both the differences in average wages (Oaxaca-Blinder technique) and in the differences throughout wage distribution, and in the levels of wage inequality (Fortin-Lemieux-Firpo technique). It should be pointed out that both techniques provide detailed decompositions which make it possible to ascertain the isolated effect of each individual explanatory variable. This is particularly appropriate as although the relative characteristics of those employed in the hospitality sector are associated in general with lower wages, this is not always the case. Therefore it is helpful to be able to differentiate between potentially opposing effects.

\subsection{Econometric decompositions: average wage differences}

Table 3 shows the results of the breakdown of average wage differences between the hospitality sector and the rest of the private sector obtained using the Oaxaca-Blinder technique. This information includes the magnitude of the average wage differential, the values of the two components (characteristics and returns) of the right-hand side of the equation (2) as well as the detailed results of the component of characteristics based on the contribution of each individual explanatory variable. A positive value of any of these components indicates that this is an element which gives rise to an unfavourable wage gap for individuals working in the hospitality industry.

The explanatory variables considered in the empirical analysis cover both individuals' characteristics and those of their jobs and the companies employing them. The former concern controls relating to the individual's gender, nationality, years of education and experience. The attributes of jobs are occupation (three categories corresponding to low-, medium- and highlyqualified occupations respectively); ${ }^{12}$ tenure in the current employment and their quadratic form; type

\footnotetext{
11 Analyses of the wage gap for women, immigrants and individuals covered by the sector collective agreement in Spain can be found in Murillo and Simón (2014), Simón et al. (2008) and Card and De la Rica (2006).

12 Highly qualified occupations include managers and directors, professionals and technicians and professional scientists and support staff (main groups 1 to 3 of the occupational classifications CNO-94 and CNO-11); low-
} 
of contract (permanent or fixed-term); the type of working day (full-time or part-time) and the performance of supervisory tasks. Finally, the attributes of the companies are size (six strata); the region where they were located and the type of collective agreement (distinguishing between company, national sector or infra-national sector agreements).

The results of the breakdown show that the disadvantage in average wages in the hospitality sector is almost totally explained by differences in endowments of characteristics, with the contribution of the coefficient component being scarcely relevant. As an example, in 2010 the entire wage disadvantage of the hospitality industry ( 0.232 logarithmic points) was explained by its worse level of endowments of characteristics (0.229) with the differences in returns having an almost negligible role ( 0.03 points, not being this component statistically different from zero). For the remaining years the results are very similar, as the contribution of the component of coefficients is not statistically significant at conventional levels, with the sole exception of 2006, when it is slightly negative (-0.027 points) and statistically different from zero.

In order to test the extent to which these results are specific to the hospitality sector, the previous analysis has been extended to other low-wage sectors of the Spanish economy. ${ }^{13}$ Thus, table 4 contains the decomposition of the difference between the average wages of those two sectors that, like the hospitality industry, exhibit wages significantly below the national average, and those of the rest of the economy. ${ }^{14}$ Very interestingly, and in contrast to the hospitality sector, a significant portion of lower wages in other low-wage sectors is due to the returns component (this factor actually explains between $40 \%$ and $60 \%$ of the differences in the raw wage gap, depending on the sector and year, respectively). Therefore unlike in the hospitality sector, workers' wages in other low-wage sectors are generally lower than those of observationally similar individuals working in the rest of the Spanish economy. These differences between hospitality and other low-wage sectors are plausibly explained by the characteristics of collective bargaining in Spain. This is an institution that has a strong influence on wage setting in the Spanish labour market because of its very high coverage (around $80 \%$ of the workforce) and its binding nature (minimum wages agreed in sectoral level agreements, those with a higher prevalence, are applicable by law to all firms and workers in the sector). Previous studies actually suggest that sectoral minimum wages exhibit a significant heterogeneity and are significantly correlated with actual wages across sectors and also that whereas

qualified occupations are basic occupations (main group 9 of the occupational classifications CNO-94 and CNO-11) and those of medium qualification the rest (main groups 4 to 8 of the occupational classifications CNO-94 and CNO11). Note that in the 2010 wave a new occupational classification is used in relation to the previous EES waves (CNO11 instead of CNO-94).

${ }^{13}$ We thank this suggestion to an anonymous referee.

14 As previously noted in the description of the EES, the use in the different waves of this dataset of different classifications sectors (NACE-93 and NACE-09, respectively) requires the use of broad sections as sector references. 
agreed minimum wages in other low-wage sectors are comparatively low, agreed wages in the hospitality sector do not significantly differ from the national average (for details see CasadoDíaz and Simón, 2008, and Simón, 2010).

The detailed decomposition carried out allows to isolate the individual contribution of each of the characteristics considered and shows that among the explanatory factors for lower wages in the hospitality sector stand out the characteristics of individuals (such as gender or education) and also attributes of their jobs (such as tenure or occupation) and, to a much lesser degree, characteristics of companies (such as the size of the company and the type of collective agreement). The two characteristics which, in any case, are more relevant in this respect are education and occupation, as the lower endowments of these two attributes for hospitality sector wage earners explains jointly between $57 \%$ and $69 \%$ of the wage gap compared to the rest of the private sector based on the year considered. Conversely, the effects of the few characteristics that operate in favour of hospitality wages (as occurs in the case of experience and supervision) have very little quantitative relevance.

\subsection{Econometric decompositions: differences throughout wage distribution}

Figure 3 shows the estimated coefficients through the unconditional quantile regression method on which the decomposition methodology proposed by Fortin, Lemieux and Firpo (2011) is based (hereinafter, FFL). Those coefficients measure the impact of each explanatory factor on different quantiles of the unconditional distribution of wages and, as in the previous sub-section, correspond to the results obtained by jointly considering the characteristics of individuals, jobs and companies as explanatory variables. For reasons of space, the results presented correspond to 2010, as they are very similar for the remainder of the years in question (more detailed information on all the coefficients of the explanatory variables can be found in tables A.2 and A.3 of appendix).

This evidence confirms that in some cases there are significant differences between the wage determination mechanisms in the hospitality industry and the rest of the private sector in Spain, as well as the fact that these differences are not homogeneous throughout the wage distribution. Thus, in the case of the hospitality sector lower wage returns are noted for education, experience and tenure, which is consistent with recent evidence on lower wage returns of human capital in the Spanish tourism sector (Casado-Díaz and Lillo-Bañuls, 2012). With regard to the impact of the type of contract, the unfavourable wage treatment for workers with a fixed-term contract which is generally observed in Spain (De la Rica, 2004) does not appear to exist in the hospitality industry. Finally, with respect to the remaining factors, the negative impact on wages caused by part-time work in Spain (see Fernández-Kranz and Rodríguez-Planas, 2011) is more attenuated in the hospitality industry, whereas the effect on wages of supervision over other workers is relatively similar to the rest of the economy. 
On the other hand, figure 4 contains the results of the aggregated decomposition of the differences in wage distributions of hospitality sector and the rest of the private sector obtained through application of the FFL technique. More specifically, the figure provides a graphic representation of the results of the decomposition of the difference of the logarithm of the hourly wage, based on the aggregated contribution of the returns and characteristics components of twenty quantiles of the wage distribution evenly distributed. In turn, table 5 and figure 5 show the detailed results of the decomposition of the quantiles obtained for the component of characteristics applying that methodology. For the purpose of easing the presentation in that figure the explanatory factors are grouped based on whether they are characteristics of individuals (gender, nationality, age and studies), jobs (tenure, type of contract, type of working day, supervision and occupation) or those of companies (size, region and type of collective agreement). The results corresponding to the different individual explanatory variables can be found in figure A.1 of the appendix.

This evidence confirms that although the bulk of the origin of the wage disadvantage in the hospitality sector is explained by differences in endowments of characteristics, there are some discrepancies throughout the wage distribution (figure 4). Thus, the increased profile of wage differences observed between hospitality and the rest of the economy coincides with a profile of the characteristics component which is also increasing. Notwithstanding this fact, the contribution of this component is comparatively greater on the left side of the distribution, in which it takes values that exceed the wage differential observed between sectors, with the subsequent contrary circumstance observed in the right part. Consequently, the contribution of the returns component is favourable for individuals employed in the hospitality industry in the low part of the distribution and unfavourable in the high part, which suggests that, unlike the rest of workers, the most qualified individuals are penalised for working in the hospitality industry, as they earn a lower wage than that which they would obtain with their same characteristics in the rest of the private sector.

The results of the detailed decomposition of the characteristics component (figure 5) show that different endowments of individual and, in particular, job characteristics are those which make a more significant contribution to the wage differential between the hospitality industry and the rest of the private sector throughout the wage distribution whereas, conversely, the contribution of the characteristics of firms is less relevant. Furthermore, it is confirmed that the increased profile observed for the overall component of characteristics is repeated in turn, in all the sub-groups of explanatory variables. When a distinction is made between the different individual explanatory variables, it is also confirmed that those which have greater explanatory power are education and occupation (figure A.1 of the appendix), which confirms that lower wages in the hospitality industry are due partly to lower educational levels of their workers and the greater presence of these in occupations that require low levels of qualification. By way of example, these two elements jointly 
explain a very high proportion of the differential in median wages between hospitality and the rest of the private sector, which range from $69 \%$ to $77 \%$ based on the year under consideration.

Finally, the evidence obtained on the origin of the differences in wage inequality (measured by the Gini index), confirms that the lower wage inequality in the hospitality industry relative to the rest of the Spanish private sector is almost fully explained by the contribution of the returns component and not by a composition effect, as the relative endowments of characteristics of individuals and jobs in hospitality explain only a minor part of its lower wage inequality (table 6). This result is fully consistent with previous evidence that qualified workers are penalized in wage terms in the hospitality sector relative to observationally similar workers in the rest of the Spanish economy. It also confirms that, ultimately, the lower wage inequality in the hospitality sector is not explained by the relative characteristics of individuals and firms in this sector, but by the specific characteristics of its wage determination mechanism.

\section{Conclusions}

This article examines wage differences between the hospitality sector and the rest of the private sector in Spain during the period 2002-2010 on the basis of a rich matched employeremployee dataset and of various econometric decomposition methodologies which permit a detailed examination of the origin of differences in relative wages. Spain is a particularly interesting analytical case because tourism has a remarkable weight both in terms of GDP and total employment to the point where in both cases said magnitudes duplicate the average values of the member states of the OECD.

The evidence obtained, consisting of results which are roughly similar for all years considered, unveils the existence of very relevant differences between wage distributions in the hospitality sector and the rest of the economy. Thus, although the wage disadvantage of the hospitality sector is observed throughout the whole wage distribution, it has an increased profile, as it is comparatively reduced for individuals with lower wages, but particularly high for those with higher wages. Moreover, the hospitality sector is characterised by having lower levels of wage inequality. In addition, it is also observed that there are extremely significant differences in the endowments of productive characteristics (as, with a few exceptions, in the hospitality industry there is a greater presence of workers and jobs with characteristics generally associated with lower wages) and among the wage-setting mechanisms of the hospitality sector and the rest of the private sector in Spain. Overall this descriptive evidence confirms and updates previous knowledge on the issue, which in many cases was based on fragmented evidence and out-of-date data.

In any case, the main contribution of the paper lays in the thorough consideration of the relative merits that characteristics and their associated returns have in explaining the origin of the 
lower wages in the hospitality sector. In other words, it is well documented that in the tourism sector, and specifically in the hospitality subsector, there is a high concentration of workers and jobs with features which are traditionally associated with low wages, and that this fact derives in a composition effect that makes hospitality a perfect candidate for being a low-wage sector. However, very little attention has been paid to whether the returns of such characteristics act in a way that compensates or complements this tendency towards lower wages. This is an issue which is tackled here through the use of different decomposition methodologies. In this vein, the evidence obtained shows that the lower wages paid in the hospitality industry compared to those in the rest of the economy are almost completely explained by differences in endowments of characteristics. This is a pattern which differs to that of other Spanish low-wage sectors where the relative contributions of the characteristics and the returns components are more balanced; this is something that might be explained by the characteristics of collective bargaining in Spain, given that agreed wages in the hospitality sector do not differ significantly from the national average whilst they are comparatively low in other low-wage sectors. Moreover, the strong predominance of the characteristics effects in the case of hospitality occurs both in regard to average wages and, in general, to the differences observed throughout the wage distribution. Furthermore, the detailed results arising from the econometric decompositions allow the quantification of the relative contribution of the diverse characteristics in explaining the differences in the wage structure of the hospitality sector and the rest of the economy. In this respect, in general, the salient explanatory factors pertain both to the characteristics of individuals and their jobs (to the detriment of firm characteristics), with the influence of differences in educational qualifications and occupational distributions being particularly significant.

One additional relevant finding of the paper is the identification of an exception to the general pattern observed. This derives from the fact that the contribution of the returns component is relevant and unfavourable in the higher part of the wage distribution for individuals employed in the hospitality sector, what suggests that the most qualified individuals are penalised for working there. The combination of the relatively good treatment received by lower paid workers in hospitality (since, in contrast with other low-wage sectors, their characteristics are not penalised in wage terms) and the penalisation suffered by more qualified individuals result in a scheme of incentives that may contribute to a self-reinforcing process in terms of the average qualification in the sector. This might result in a perpetuation of its lack of capacity for attracting and retaining qualified labour and constitutes one of the largest risks identified by organisms like the OECD (2012). It is noteworthy, however, that the penalisation suffered by those earning higher wages is precisely the main explanation for the lower levels of wage inequality that characterise hospitality, a fact that allows this sector to mitigate income inequality levels in 
Spain, thanks to its significant weight in the overall economy. This contribution is relevant since it is recognised that income inequality has important impacts on aspects such as social cohesion and economic growth (Forbes, 2000 and Halter et al., 2014), on the one hand, and that the values reached by this variable in Spain are among the largest in advanced countries and among those experiencing a highest growth in OECD countries as a result of the Great Recession (Cingano, 2014), on the other. 


\section{References}

Abowd, J.M. \& Kramarz, F. (1999). The Analysis of Labor Markets Using Matched Employer-Employee Data, in O. Ashenfelter and D. Card (ed.) Handbook of Labor Economics, Vol. 3, 2629-2710. Elsevier.

Blinder, A. S. (1973). Wage discrimination: reduced forms and structural estimates. Journal of Human Resources, 8, 436-55.

Brida, J.G.; Cortes-Jimenez, I., \& Pulina, M. (2014). Has the tourism-led growth hypothesis been validated? A literature review. Current Issues in Tourism. DOI: 10.1080/13683500.2013.868414

Campos-Soria, J.A., García-Pozo, A., Sánchez-Ollero, J.L., \& Benavides-Chicón, C.G. (2011a). A Comparative Analysis of Human Capital and Wage Structure in the Spanish Hospitality Sector. Journal of Service Science and Management, 4, 458-468.

Campos-Soria, J.A., Marchante-Mera, A., \& Ropero-García, M.A. (2011b). Patterns of occupational segregation by gender in the hospitality industry. International Journal of Hospitality Management 30, 91102.

Card, D. \& de la Rica, S. (2006). Firm-level Contracting and the Structure of Wages. Industrial and Labor Relations Review, 59(4), 573-593.

Casado-Díaz, J.M.; Simón, H. (2008): "Industry Wage Premia and Collective Bargaining Revisited: Evidence from Spain”, Applied Economics Letters, 15, pp. 477-481.

Cingano, F. (2014). Trends in Income Inequality and its Impact on Economic Growth. OECD Social, Employment and Migration Working Papers, No. 163.

De la Rica, S. (2004). Wage gaps between workers with indefinite and fixed-term contracts: The impact of firm and occupational segregation. Moneda y Crédito, 219, 43-69.

Di Nardo, J., Fortin, N.M., \& Lemieux, T. (1996). Labor market institutions and the distribution of wages, 1973-1992: A semi-parametric approach. Econometrica, 64 (5), 1011-1044.

Elder, T.E., Goddeeris, J.H., \& Haider, S. J. (2010). Unexplained gaps and Oaxaca-Blinder decompositions. Labour Economics, 17(1), 284-290.

Fernández, M.; Pena-Boquete, Y., \& Pereira, X. (2009). Labor Conditions in the Spanish Hotels and Restaurants Industry. Tourism Analysis, 14(3), 293-312.

Fernández-Kranz, D. \& Rodríguez-Planas, N. (2011). The part-time pay penalty in a segmented labor market. Labour Economics, 18(5), 591-606.

Forbes, K.J. (2000). A reassessment of the relationship between inequality and growth. American Economic Review, 90(4), 869-887.

Fortin, N.; Lemieux, T., \& Firpo, S. (2011). Decomposition Methods in Economics. In D. Card and O. Ashenfelter (Eds.) Handbook of Labor Economics, Volume 4 (pp. 1-102). Elsevier.

García-Pozo, A., Campos-Soria, J.A., Sánchez-Ollero, J.L., \& Marchante-Lara, M. (2012). The regional wage gap in the Spanish hospitality sector based on a gender perspective. International Journal of Hospitality Management, 31, 266-275.

García-Pozo, A., Marchante-Mera, A.J., \& Sánchez-Ollero, J.L. (2011). Occupational differences in the return on human capital in the Spanish travel agency and hospitality industries. Tourism Economics, 17(6), 1325-1345.

Gerogiannis, E.; Kerkofs, P., \& Vargas, O. (2012). Employment and industrial relations in the hotels and restaurants sector - EU countries. European Foundation for the Improvement of Living and Working Conditions. Eironline - European Industrial Relations Observatory On-line.

Halter D., Oechslin, M., \& Zweimüller, J. (2014). Inequality and growth: the neglected time dimension. Journal of Economic Growth, 19(1), 81-104.

Hamermesh, D. (2008). Fun with matched firm-employee data: Progress and road maps. Labour Economics, 15(4), 662-672.

Juhn, C., Murphy, K., \& Pierce, B. (1993). Wage inequality and the rise in returns to skill. Journal of Political Economy, 101, 410-442.

Ladkin, A. (2011). Exploring tourism labor. Annals of Tourism Research, 38(3), 1135-1155.

Lee, C-K., \& Kang, S. (1998). Measuring earnings inequality and median earnings in the tourism industry, Tourism Management, 19(4), 341-348.

Lillo-Bañuls, A., \& Casado-Díaz, J.M. (2010). Rewards to education in the tourism sector: one step ahead. Tourism Economics, 16(1), 11-23.

Lillo-Bañuls, A., \& Casado-Díaz, J.M. (2012). Individual returns to education in the Spanish tourism sector during the crisis. Tourism Economics, 18(6), 1229-1249.

Lillo- Bañuls, A. \& Casado-Díaz, J.M. (2015). Exploring the relationship between educational mismatch, earnings and job satisfaction in the tourism industry during the global economic crisis. Current Issues in Tourism, 18(4), 361-375. DOI:10.1080/13683500.2014.915796. 
Lillo-Bañuls, A., \& Ramón-Rodríguez, A.B. (2005). Returns on education in the Spanish tourism labour market. Tourism Economics, 11(1), 119-132.

Liu, A. \& Wall, G. (2005). Human Resources Development in China. Annals of Tourism, 32(3), 689-710.

Machado, J. A., \& Mata, J. (2005). Counterfactual decomposition of changes in wage distribution using quantile regression. Journal of Applied Econometrics, 20, 445-465.

Marchante, A.J., Ortega, B., \& Pagán, R. (2005). Educational mismatch and wages in the hospitality sector. Tourism Economics, 11(1), 103-117.

Melly, B. (2006). Estimation of counterfactual distributions using quantile regression. Mimeo, Swiss Institute for International Economics and Applied Economic Research, University of St. Gallen.

Muñoz-Bullón, F. (2009). The gap between male and female pay in the Spanish tourism industry. Tourism Management, 30, 638-649.

Murillo, I.; Simón, H. (2014). La Gran Recesión y el diferencial salarial por género en España. Hacienda Pública Española / Review of Public Economics, 208, 39-76. DOI: 10.7866/HPE-RPE.14.1.2

Neumark, D. (1988). Employer's discriminatory behaviour and the estimation of wage discrimination. Journal of Human Resources, 23, 279-295.

OECD. (2012). OECD Tourism trends and policies 2012. Paris: OECD Publishing.

OECD (2014). OECD Tourism Trends and Policies 2014. Paris: OECD Publishing.

Oaxaca, R. (1973). Male-female wage differentials in urban labour markets. International Economic Review, Vol. 14, pp. 693-709.

Oaxaca, R., \& Ransom, M. (1994). On discrimination and the decomposition of wage differentials. Journal of Econometrics, 61, 5-22.

Pestana, C., \& Santos, C.M. (2009). Earnings of hotel managers: comparing the human and social capital approach. Tourism Economics, 15(1), 87-103.

Riley, M., Ladkin, A. \& Szivas, E. (2002). Tourism employment: Analysis and planning. Clevedon: Chanel View.

Riley, M., \& Szivas, E. (2003). Pay Determination. A Socioeconomic Framework. Annals of Tourism Research, $30(2), 446-464$.

Santos, L.D., \& Varejão, J. (2007). Employment, pay and discrimination in the tourism industry. Tourism Economics, 13(2), 225-240.

Sanz, P. (2012). Employment and Industrial Relations in the Hotels and Restaurants - Spain. European Foundation for the Improvement of Living and Working Conditions - Eironline (European Industrial Relations Observatory On-line.

Simón, H.; Ramos, R. \& Sanromá, E. (2008). Labour Segregation and Immigrant and Native-born Wage Distributions in Spain: An Analysis Using Matched Employer-Employee Data. Spanish Economic Review, vol. 10(2), 135-168.

Simón, H. (2010): "La negociación colectiva y la estructura salarial en España”, Papeles de Economía Española, $\mathrm{n}^{\mathrm{o}} 124$, pp. 214-228.

Sinclair, M.T. (1997). Gender, Work and Tourism. Routledge: London.

Sinclair, M.T. and Stabler, M. (1997). The Economics of Tourism. Routledge: London.

Skalpe, O. (2007). The CEO gender pay gap in the tourism industry - Evidence from Norway. Tourism Management, 28, 845-853.

Sturman, M.C. (2001). The Compensation Conundrum. Does the Hospitality Industry Shortchange Its Employees - and Itself? Cornell Hotel and Restaurant Administration Quarterly, August, 70-76.

Thrane, C. (2008). Earnings differentiation in the tourism industry: Gender, human capital and sociodemographic effects. Tourism Management, 29, 514-524.

Thrane, C. (2010). Education and earnings in the tourism industry - the role of sheepskin effects. Tourism Economics, 16(3), 549-563.

Turespaña (several years) Social security registration. Annual data. Madrid: Turespaña.

Xiao, H., \& Smith, S. (2006). The making of tourism research: Insights from a social sciences journal. Annals of Tourism Research, 33(2), 490-507. 
Figure 1.

Wage distribution in the hospitality sector and the rest of the private sector. 2002, 2006 and 2010.

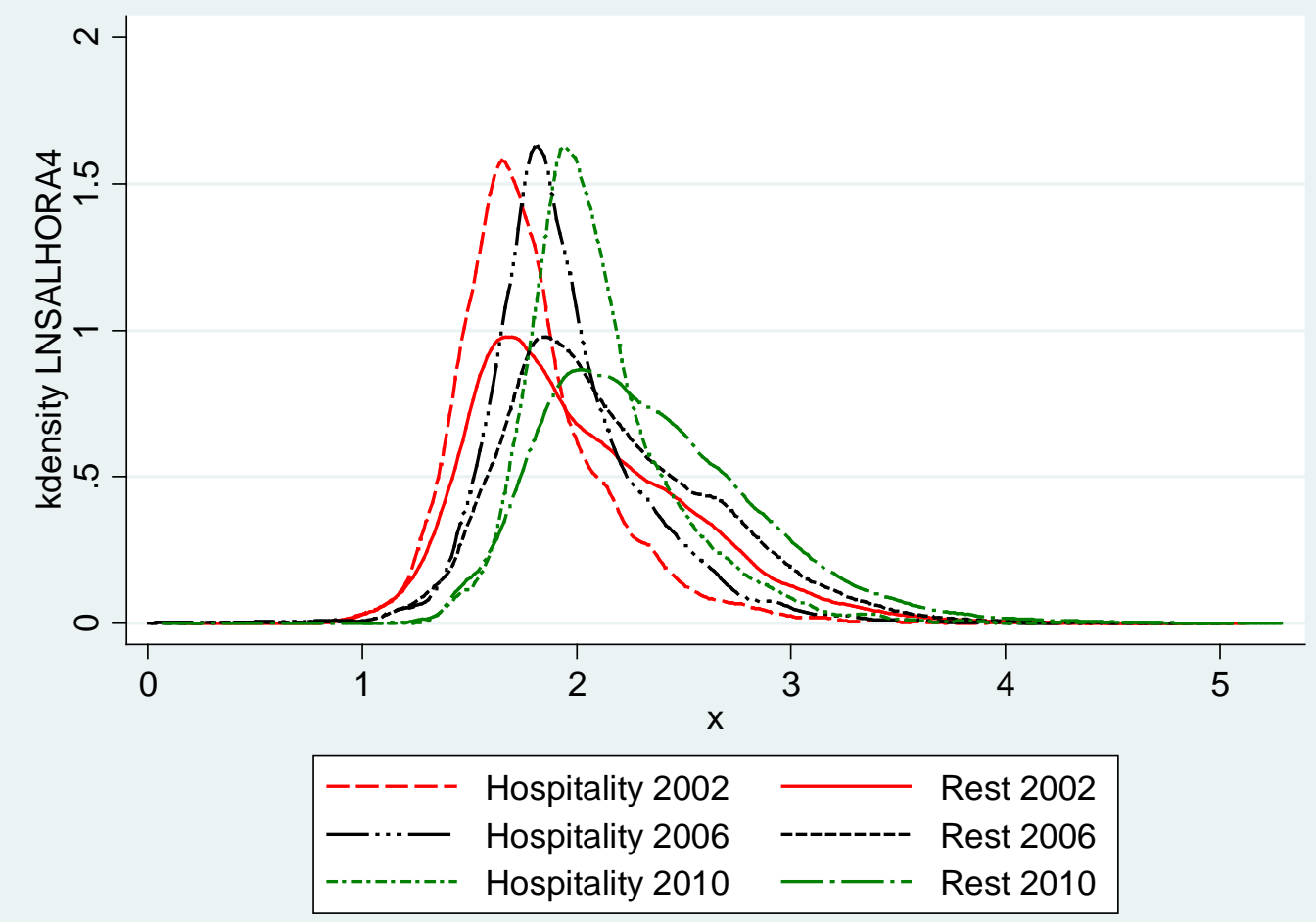

Notes: The figure contains the kernel density function of the logarithm of the hourly wage. 
Figure 2.

Wage differentials between the hospitality sector and the rest of the private sector in Spain.

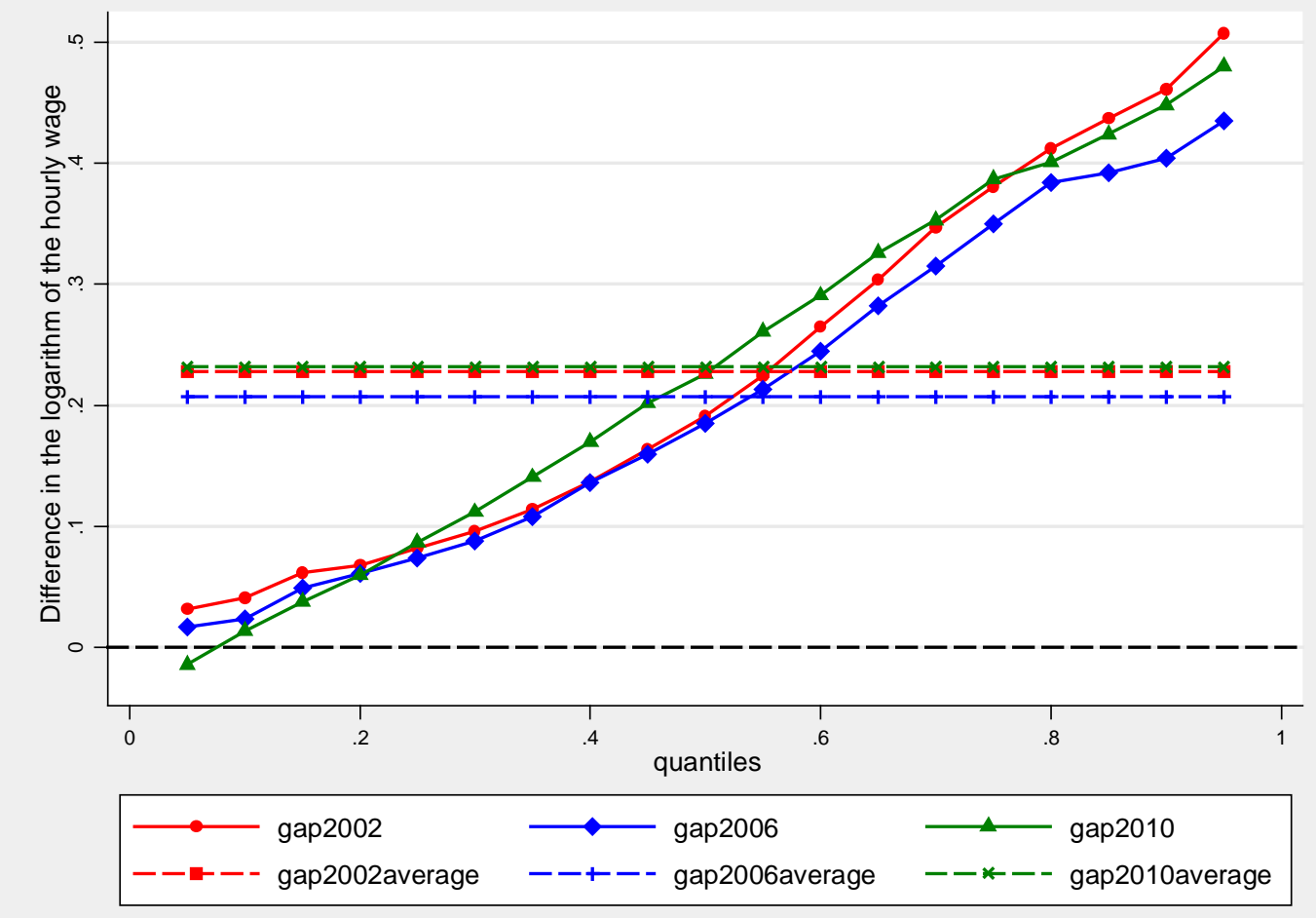


Figure 3.

Coefficients of the unconditional quantile regressions.

Individual and job (selected) characteristics.
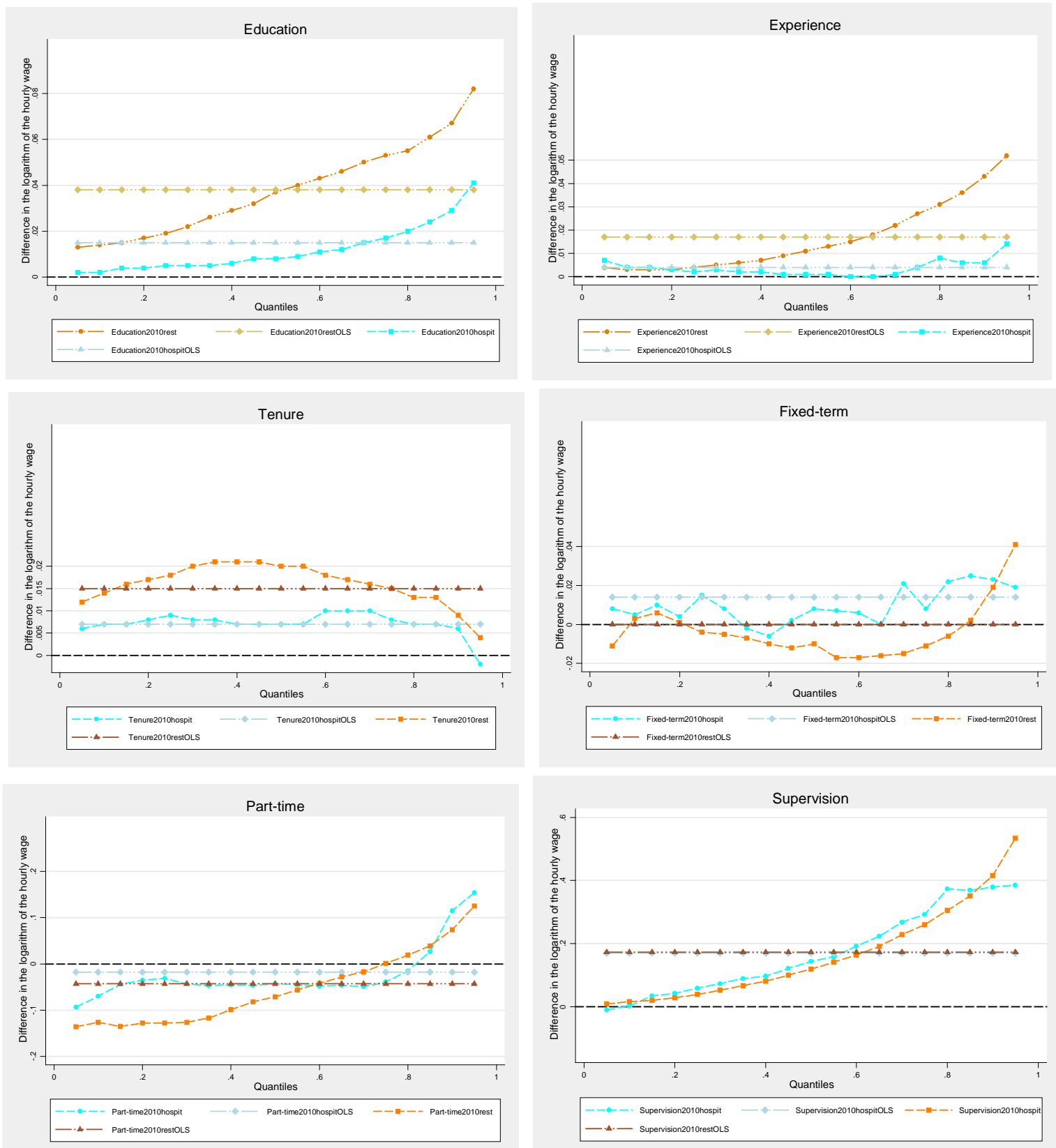
Figure 4.

Aggregate decomposition of the wage gap between the hospitality sector ant the rest of the economy.

2002
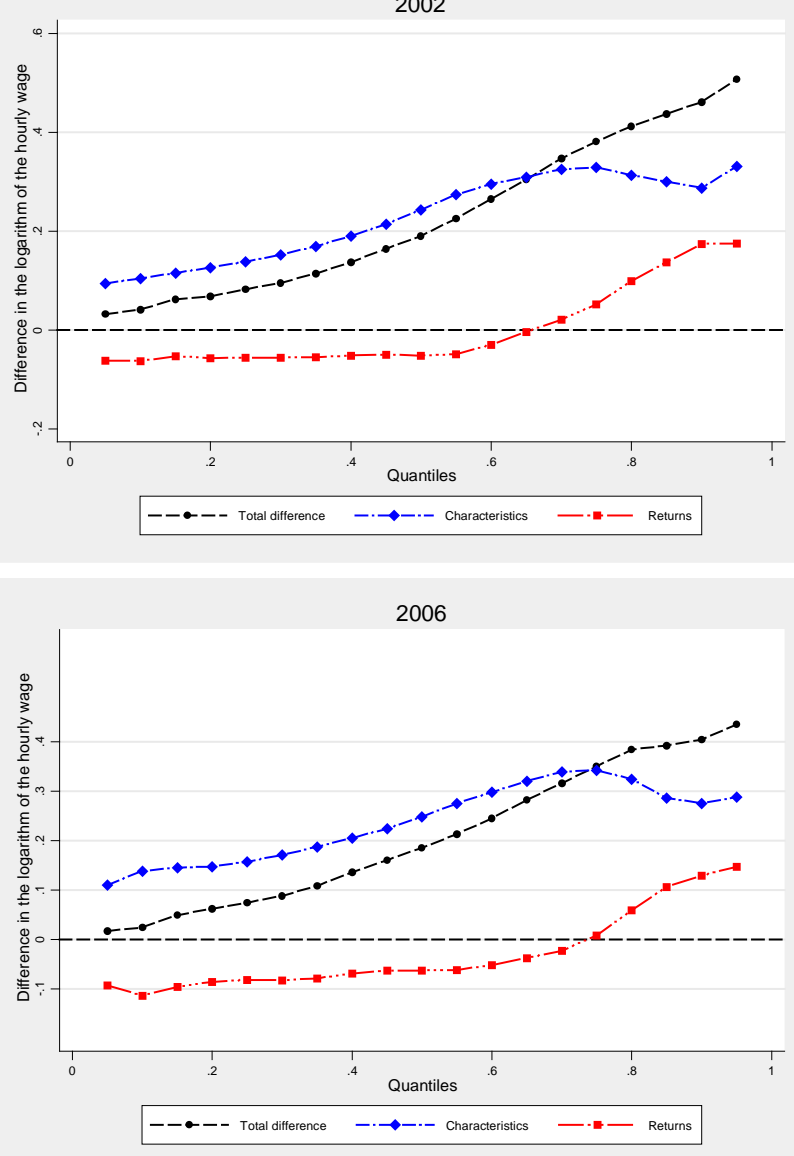

2010

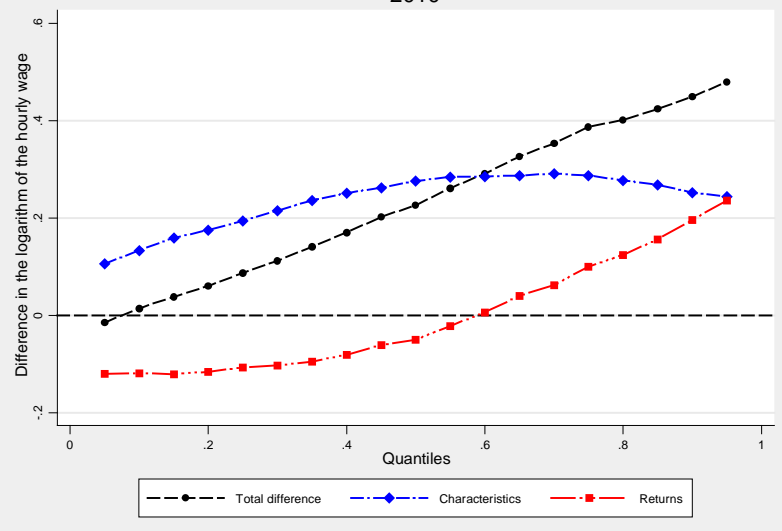


Figure 5.

Detailed decomposition of the wage gap between the hospitality sector ant the rest of the economy. Characteristics component.
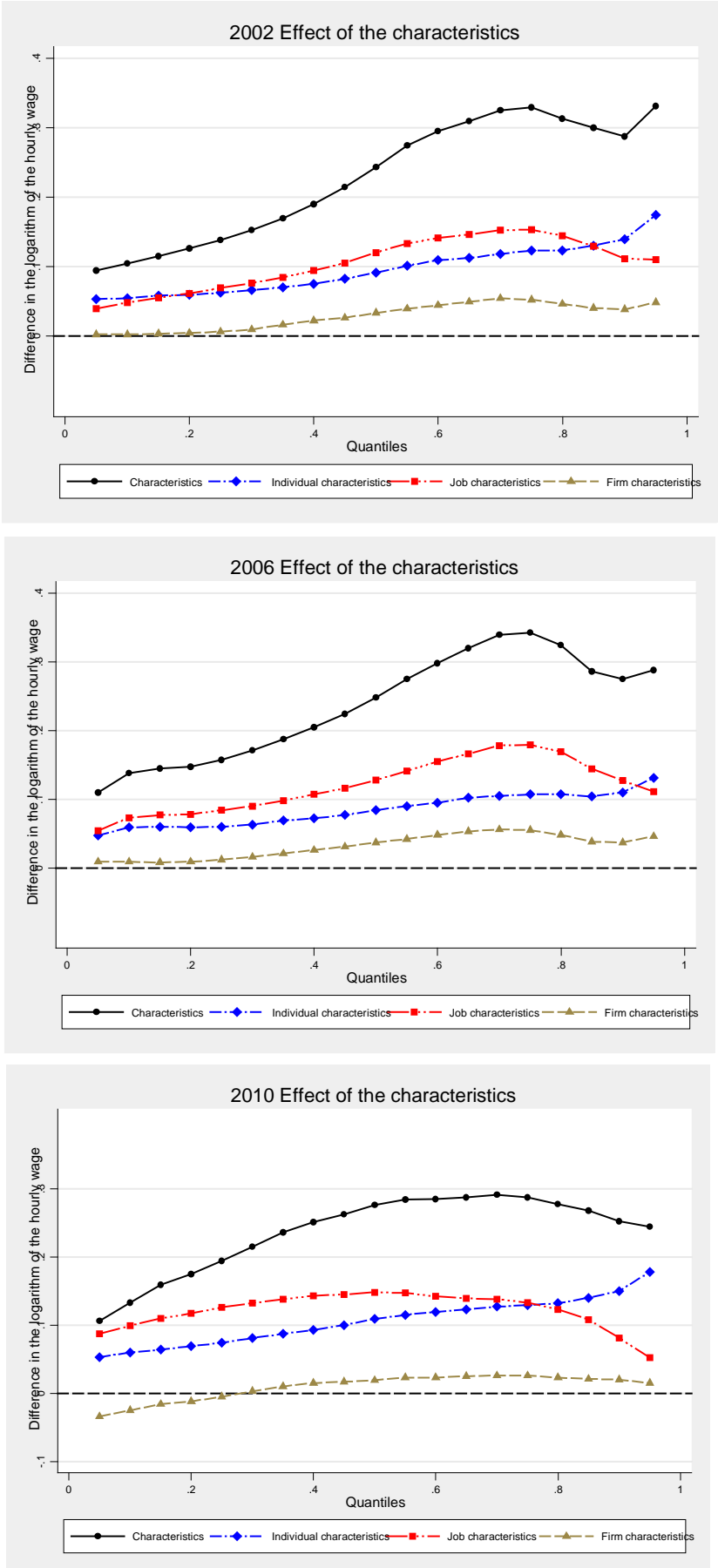
Table 1.

Wage differentials between the hospitality sector and the rest of the private sector in Spain.

\begin{tabular}{|c|c|c|c|}
\hline & 2002 & 2006 & 2010 \\
\hline Average & 0.228 & 0.207 & 0.232 \\
\hline \multicolumn{4}{|l|}{ Percentiles } \\
\hline 10 & 0.041 & 0.024 & 0.014 \\
\hline 20 & 0.068 & 0.061 & 0.060 \\
\hline 30 & 0.096 & 0.088 & 0.112 \\
\hline 40 & 0.137 & 0.136 & 0.170 \\
\hline 50 & 0.191 & 0.185 & 0.226 \\
\hline 60 & 0.265 & 0.245 & 0.291 \\
\hline 70 & 0.347 & 0.315 & 0.353 \\
\hline 80 & 0.412 & 0.384 & 0.401 \\
\hline 90 & 0.461 & 0.404 & 0.449 \\
\hline
\end{tabular}

Notes: Difference in the logarithm of the hourly wage. Hourly wages are measured in current terms.

Table 2.

Wage inequality in the hospitality sector and the rest of the private sector in Spain.

Gini index.

\begin{tabular}{lccc}
\hline & 2002 & 2006 & 2010 \\
\hline Rest of the private sector & 0.137 & 0.128 & 0.119 \\
Hospitality & 0.104 & 0.101 & 0.088 \\
Difference & $-0.033^{*}$ & $-0.027 *$ & $-0.031^{*}$ \\
\hline
\end{tabular}

$*$ indicates that the difference between the two sectors is statistically significant at $1 \%$. 
Table 3.

Decomposition of wage differentials between the hospitality sector and the rest of the private sector in Spain. Average wages and Oaxaca-Blinder technique.

\begin{tabular}{|c|c|c|c|c|}
\hline & & 2002 & 2006 & 2010 \\
\hline \multirow[t]{10}{*}{ Total } & \multirow[t]{2}{*}{ Rest of the economy } & 2.015 & 2.158 & 2.342 \\
\hline & & $(0.001)^{* * *}$ & $(0.001)^{* * *}$ & $(0.001)^{* * *}$ \\
\hline & \multirow[t]{2}{*}{ Hospitality } & 1.787 & 1.951 & 2.109 \\
\hline & & $(0.004)^{* * *}$ & $(0.004)^{* * *}$ & $(0.005)^{* * *}$ \\
\hline & \multirow[t]{2}{*}{ Difference } & 0.228 & 0.207 & 0.232 \\
\hline & & $(0.004) * * *$ & $(0.004)^{* * *}$ & $(0.005)^{* * *}$ \\
\hline & \multirow[t]{2}{*}{ Characteristics } & 0.224 & 0.233 & 0.229 \\
\hline & & $(0.003)^{* * *}$ & $(0.003)^{* * *}$ & $(0.005)^{* * *}$ \\
\hline & \multirow[t]{2}{*}{ Coefficients } & 0.004 & -0.027 & 0.003 \\
\hline & & $(0.004)$ & $(0.004)^{* * *}$ & $(0.005)$ \\
\hline \multirow[t]{24}{*}{ Characteristics } & \multirow[t]{2}{*}{ Gender } & 0.042 & 0.036 & 0.034 \\
\hline & & $(0.001)^{* * *}$ & $(0.001)^{* * *}$ & $(0.001)^{* * *}$ \\
\hline & \multirow[t]{2}{*}{ Nationality } & -0.001 & -0.002 & -0.001 \\
\hline & & $(0.000)^{* * *}$ & $(0.000)^{* * *}$ & $(0.000)^{*}$ \\
\hline & \multirow[t]{2}{*}{ Experience } & -0.003 & -0.004 & -0.010 \\
\hline & & $(0.001)^{* * *}$ & $(0.001)^{* * *}$ & $(0.001)^{* * *}$ \\
\hline & \multirow[t]{2}{*}{ Education } & 0.057 & 0.055 & 0.083 \\
\hline & & $(0.001)^{* * *}$ & $(0.001)^{* * *}$ & $(0.002) * * *$ \\
\hline & \multirow[t]{2}{*}{ Tenure } & 0.028 & 0.031 & 0.031 \\
\hline & & $(0.001)^{* * *}$ & $(0.001)^{* * *}$ & $(0.001)^{* * *}$ \\
\hline & \multirow[t]{2}{*}{ Type of contract } & 0.000 & 0.000 & 0.000 \\
\hline & & $(0.000)$ & $(0.000)$ & $(0.000)$ \\
\hline & \multirow[t]{2}{*}{ Full-time/Part-time } & -0.001 & 0.006 & 0.011 \\
\hline & & $(0.000)^{*}$ & $(0.000)^{* * *}$ & $(0.001)^{* * *}$ \\
\hline & \multirow[t]{2}{*}{ Supervision } & 0.000 & -0.004 & -0.004 \\
\hline & & $(0.001)$ & $(0.001)^{* * *}$ & $(0.001)^{* * *}$ \\
\hline & \multirow[t]{2}{*}{ Occupation } & 0.074 & 0.084 & 0.077 \\
\hline & & $(0.001)^{* * *}$ & $(0.001)^{* * *}$ & $(0.001)^{* * *}$ \\
\hline & \multirow[t]{2}{*}{ Region } & 0.001 & 0.004 & 0.002 \\
\hline & & $(0.001)^{*}$ & $(0.001)^{* * *}$ & $(0.001)^{* *}$ \\
\hline & \multirow[t]{2}{*}{ Size } & 0.012 & 0.020 & -0.007 \\
\hline & & $(0.001)^{* * *}$ & $(0.001)^{* * *}$ & $(0.001)^{* * *}$ \\
\hline & \multirow[t]{2}{*}{ Collective agreement } & 0.014 & 0.007 & 0.012 \\
\hline & & $(0.001)^{* * *}$ & $(0.001)^{* * *}$ & $(0.001)^{* * *}$ \\
\hline$N$ & & 122,432 & 140,241 & 164,648 \\
\hline
\end{tabular}

${ }^{*} p<0.1$; ** $p<0.05$; *** $p<0.01$ 
Table 4.

Decomposition of wage differentials between low-wage sectors and the rest of the private sector in Spain.

\begin{tabular}{|c|c|c|c|c|c|c|c|c|c|c|}
\hline & & \multicolumn{3}{|c|}{$\begin{array}{c}\text { Hospitality } \\
\text { (NACE-93 Section H) }\end{array}$} & \multicolumn{3}{|c|}{$\begin{array}{l}\text { Real state and rental } \\
\text { (NACE-93 section K) }\end{array}$} & \multicolumn{3}{|c|}{$\begin{array}{c}\text { Other social activities and services } \\
\text { (NACE-93 section O) }\end{array}$} \\
\hline & & 2002 & 2006 & 2010 & 2002 & 2006 & 2010 & 2002 & 2006 & 2010 \\
\hline \multirow[t]{5}{*}{ Total } & Rest of the economy & $\begin{array}{c}2.015 \\
(0.001)^{* * *}\end{array}$ & $\begin{array}{c}2.158 \\
(0.001)^{* * *}\end{array}$ & $\begin{array}{l}2.342 \\
(0.001) * * *\end{array}$ & $\begin{array}{l}2.018 \\
(0.001)^{* * *}\end{array}$ & $\begin{array}{l}2.170 \\
(0.001)^{* * *}\end{array}$ & $\begin{array}{l}2.368 \\
(0.001)^{* * *}\end{array}$ & $\begin{array}{l}2.006 \\
(0.001)^{* * *}\end{array}$ & $\begin{array}{l}2.146 \\
(0.001)^{* * *}\end{array}$ & $\begin{array}{l}2.341 \\
(0.001) * * *\end{array}$ \\
\hline & Low-wage sector & $\begin{array}{c}1.787 \\
(0.004)^{* * *}\end{array}$ & $\begin{array}{c}1.951 \\
(0.004)^{* * *}\end{array}$ & $\begin{array}{l}2.109 \\
(0.005)^{* * *}\end{array}$ & $\begin{array}{l}1.821 \\
(0.004)^{* * *}\end{array}$ & $\begin{array}{l}1.964 \\
(0.003)^{* * *}\end{array}$ & $\begin{array}{l}2.178 \\
(0.003)^{* * *}\end{array}$ & $\begin{array}{l}1.914 \\
(0.011)^{* * *}\end{array}$ & $\begin{array}{l}2.066 \\
(0.009)^{* * *}\end{array}$ & $\begin{array}{l}2.185 \\
(0.006)^{* * *}\end{array}$ \\
\hline & Difference & $\begin{array}{c}0.228 \\
(0.004)^{* * *}\end{array}$ & $\begin{array}{l}0.207 \\
(0.004)^{* * *}\end{array}$ & $\begin{array}{l}0.232 \\
(0.005)^{* * *}\end{array}$ & $\begin{array}{l}0.197 \\
(0.004)^{* * *}\end{array}$ & $\begin{array}{l}0.206 \\
(0.004)^{* * *}\end{array}$ & $\begin{array}{l}0.190 \\
(0.003)^{* * *}\end{array}$ & $\begin{array}{l}0.092 \\
(0.011)^{* * *}\end{array}$ & $\begin{array}{l}0.080 \\
(0.009)^{* * *}\end{array}$ & $\begin{array}{l}0.156 \\
(0.006)^{* * *}\end{array}$ \\
\hline & Characteristics & $\begin{array}{c}0.224 \\
(0.003)^{* * *}\end{array}$ & $\begin{array}{c}0.233 \\
(0.003)^{* * * *}\end{array}$ & $\begin{array}{l}0.229 \\
(0.005)^{* * *}\end{array}$ & $\begin{array}{l}0.099 \\
(0.003)^{* * *}\end{array}$ & $\begin{array}{l}0.097 \\
(0.003)^{* * *}\end{array}$ & $\begin{array}{l}0.085 \\
(0.002)^{* * *}\end{array}$ & $\begin{array}{l}0.044 \\
(0.008)^{* * *}\end{array}$ & $\begin{array}{l}0.033 \\
(0.006)^{* * *}\end{array}$ & $\begin{array}{l}0.092 \\
(0.004)^{* * *}\end{array}$ \\
\hline & Coefficients & $\begin{array}{c}0.004 \\
(0.004)\end{array}$ & $\begin{array}{c}-0.027 \\
(0.004)^{* * *}\end{array}$ & $\begin{array}{l}0.003 \\
(0.005)\end{array}$ & $\begin{array}{l}0.098 \\
(0.004)^{* * *}\end{array}$ & $\begin{array}{l}0.109 \\
(0.003)^{* * *}\end{array}$ & $\begin{array}{l}0.105 \\
(0.002)^{* * *}\end{array}$ & $\begin{array}{l}0.048 \\
(0.008)^{* * *}\end{array}$ & $\begin{array}{l}0.046 \\
(0.007)^{* * *}\end{array}$ & $\begin{array}{l}0.065 \\
(0.004)^{* * *}\end{array}$ \\
\hline$N$ & & 122,432 & 140,241 & 164,648 & 122,432 & 140,241 & 164,648 & 122,432 & 140,241 & 164,648 \\
\hline
\end{tabular}

$* p<0.1 ; * * p<0.05 ; * * * p<0.01$ 
Table 5.

Decomposition of wage differentials between the hospitality sector and the rest of the private sector in Spain.

\begin{tabular}{|c|c|c|c|c|c|c|c|c|c|c|}
\hline \\
\hline & & \multicolumn{3}{|c|}{2002} & \multicolumn{3}{|c|}{2006} & \multicolumn{3}{|c|}{2010} \\
\hline & & Percentile 10 & Median & Percentile 90 & $\begin{array}{c}\text { Percentile } \\
10\end{array}$ & Median & $\begin{array}{c}\text { Percentile } \\
90\end{array}$ & Percentile 10 & Median & Percentile 90 \\
\hline \multirow[t]{10}{*}{ Total } & Rest of the economy & 1.466 & 1.916 & 2.704 & 1.605 & 2.069 & 2.838 & 1.766 & 2.267 & 3.015 \\
\hline & & $(0.001)^{* * *}$ & $(0.002)^{* * *}$ & $(0.003)^{* * *}$ & $(0.002)^{* * *}$ & $(0.002)^{* * *}$ & $(0.003)^{* * *}$ & $(0.001)^{* * *}$ & $(0.002)^{* * *}$ & $(0.003)^{* * *}$ \\
\hline & Hospitality & 1.425 & 1.725 & 2.243 & 1.581 & 1.884 & 2.434 & 1.752 & 2.041 & 2.567 \\
\hline & & $(0.004)^{* * *}$ & $(0.004)^{* * *}$ & $(0.010)^{* * *}$ & $(0.004)^{* * *}$ & $(0.004)^{* * *}$ & $(0.010)^{* * *}$ & $(0.005)^{* * *}$ & $(0.005)^{* * *}$ & $(0.013)^{* * *}$ \\
\hline & Difference & 0.041 & 0.190 & 0.461 & 0.024 & 0.185 & 0.404 & 0.014 & 0.226 & 0.449 \\
\hline & & $(0.004)^{* * *}$ & $(0.004)^{* * *}$ & $(0.010)^{* * *}$ & $(0.005)^{* * *}$ & $(0.004)^{* * *}$ & $(0.010)^{* * *}$ & $(0.005)^{* * *}$ & $(0.005)^{* * *}$ & $(0.013)^{* * *}$ \\
\hline & Characteristics & 0.104 & 0.243 & 0.287 & 0.138 & 0.248 & 0.275 & 0.133 & 0.276 & 0.252 \\
\hline & & $(0.003)^{* * *}$ & $(0.004)^{* * *}$ & $(0.005)^{* * *}$ & $(0.003)^{* * *}$ & $(0.004)^{* * *}$ & $(0.005)^{* * *}$ & $(0.004)^{* * *}$ & $(0.005)^{* * *}$ & $(0.007)^{* * *}$ \\
\hline & Coefficients & -0.063 & -0.052 & 0.174 & -0.114 & -0.063 & 0.129 & -0.119 & -0.050 & 0.196 \\
\hline & & $(0.005)^{* * *}$ & $(0.004)^{* * *}$ & $(0.010)^{* * *}$ & $(0.005)^{* * *}$ & $(0.004)^{* * *}$ & $(0.009)^{* * *}$ & $(0.006)^{* * *}$ & $(0.005)^{* * *}$ & $(0.013)^{* * *}$ \\
\hline \multirow[t]{24}{*}{ Characteristics } & Gender & 0.036 & 0.042 & 0.050 & 0.036 & 0.034 & 0.038 & 0.027 & 0.035 & 0.039 \\
\hline & & $(0.001)^{* * *}$ & $(0.001)^{* * *}$ & $(0.002)^{* * *}$ & $(0.001)^{* * *}$ & $(0.001)^{* * *}$ & $(0.001)^{* * *}$ & $(0.001)^{* * *}$ & $(0.001)^{* * *}$ & $(0.002)^{* * *}$ \\
\hline & Nationality & -0.001 & -0.000 & -0.002 & -0.001 & 0.001 & -0.006 & 0.005 & 0.003 & -0.012 \\
\hline & & $(0.000)^{* *}$ & $(0.000)$ & $(0.001)^{* * *}$ & $(0.001)$ & $(0.001)^{* *}$ & $(0.001)^{* * *}$ & $(0.001)^{* * *}$ & $(0.001)^{* * *}$ & $(0.001)^{* * *}$ \\
\hline & Experience & -0.001 & -0.002 & -0.005 & -0.001 & -0.003 & -0.007 & -0.002 & -0.008 & -0.021 \\
\hline & & $(0.000)^{* * *}$ & $(0.001)^{* *}$ & $(0.002)^{* * *}$ & $(0.000)^{* * *}$ & $(0.001)^{* * *}$ & $(0.001)^{* * *}$ & $(0.000)^{* * *}$ & $(0.001)^{* * *}$ & $(0.002)^{* * *}$ \\
\hline & Education & 0.020 & 0.051 & 0.096 & 0.025 & 0.052 & 0.085 & 0.030 & 0.079 & 0.144 \\
\hline & & $(0.001)^{* * *}$ & $(0.001)^{* * *}$ & $(0.003)^{* * *}$ & $(0.001)^{* * *}$ & $(0.001)^{* * *}$ & $(0.002)^{* * *}$ & $(0.001)^{* * *}$ & $(0.002)^{* * *}$ & $(0.004)^{* * *}$ \\
\hline & Tenure & 0.014 & 0.037 & 0.026 & 0.018 & 0.035 & 0.036 & 0.020 & 0.038 & 0.032 \\
\hline & & $(0.001)^{* * *}$ & $(0.001)^{* * *}$ & $(0.002)^{* * *}$ & $(0.001)^{* * *}$ & $(0.001)^{* * *}$ & $(0.002)^{* * *}$ & $(0.001)^{* * *}$ & $(0.002)^{* * *}$ & $(0.002)^{* * *}$ \\
\hline & Type of contract & 0.000 & 0.000 & 0.000 & 0.000 & -0.001 & 0.001 & 0.000 & -0.000 & 0.000 \\
\hline & & $(0.000)$ & $(0.000)$ & $(0.000)$ & $(0.000)^{* *}$ & $(0.000)^{* * *}$ & $(0.000)^{* * *}$ & $(0.000)$ & $(0.000)$ & $(0.000)^{*}$ \\
\hline & Full-time/Part-time & 0.009 & 0.002 & -0.015 & 0.022 & 0.007 & -0.011 & 0.033 & 0.019 & -0.021 \\
\hline & & $(0.001)^{* * *}$ & $(0.001)^{* * *}$ & $(0.001)^{* * *}$ & $(0.001)^{* * *}$ & $(0.001)^{* * *}$ & $(0.001)^{* * *}$ & $(0.002)^{* * *}$ & $(0.001)^{* * *}$ & $(0.002)^{* * *}$ \\
\hline & Supervision & 0.000 & 0.000 & 0.001 & -0.000 & -0.003 & -0.009 & -0.000 & -0.003 & -0.010 \\
\hline & & $(0.000)$ & $(0.000)$ & $(0.001)$ & $(0.000)^{* * *}$ & $(0.001)^{* * *}$ & $(0.001)^{* * *}$ & $(0.000)^{* * *}$ & $(0.001)^{* * *}$ & $(0.002)^{* * *}$ \\
\hline & Occupation & 0.025 & 0.081 & 0.099 & 0.033 & 0.090 & 0.110 & 0.046 & 0.094 & 0.080 \\
\hline & & $(0.001)^{* * *}$ & $(0.002)^{* * *}$ & $(0.003)^{* * *}$ & $(0.001)^{* * *}$ & $(0.002)^{* * *}$ & $(0.002)^{* * *}$ & $(0.002)^{* * *}$ & $(0.002)^{* * *}$ & $(0.002)^{* * *}$ \\
\hline & Region & 0.003 & 0.006 & -0.009 & 0.007 & 0.006 & -0.003 & 0.008 & 0.002 & -0.006 \\
\hline & & $(0.001)^{* * *}$ & $(0.001)^{* * *}$ & $(0.002)^{* * *}$ & $(0.001)^{* * *}$ & $(0.001)^{* * *}$ & $(0.001)^{* *}$ & $(0.001)^{* * *}$ & $(0.001)^{*}$ & $(0.002)^{* * *}$ \\
\hline & Size & 0.004 & 0.012 & 0.019 & 0.006 & 0.024 & 0.026 & -0.004 & -0.007 & -0.009 \\
\hline & & $(0.001)^{* * *}$ & $(0.001)^{* * *}$ & $(0.001)^{* * *}$ & $(0.001)^{* * *}$ & $(0.001)^{* * *}$ & $(0.001)^{* * *}$ & $(0.001)^{* * *}$ & $(0.001)^{* * *}$ & $(0.001)^{* * *}$ \\
\hline & Collective agreement & -0.005 & 0.015 & 0.028 & -0.004 & 0.007 & 0.014 & -0.029 & 0.024 & 0.035 \\
\hline & & $(0.001)^{* * *}$ & $(0.001)^{* * *}$ & $(0.002)^{* * *}$ & $(0.001)^{* * *}$ & $(0.001)^{* * *}$ & $(0.002)^{* * *}$ & $(0.002)^{* * *}$ & $(0.001)^{* * *}$ & $(0.002)^{* * *}$ \\
\hline$N$ & & 122,432 & 122,432 & 122,432 & 140,241 & 140,241 & 140,241 & 164,648 & 164,648 & 164,648 \\
\hline
\end{tabular}


Table 6.

Decomposition of wage differentials between the hospitality sector and the rest of the private sector in Spain. Wage inequality (Gini index) and Fortin-Lemieux-Firpo technique.

\begin{tabular}{|c|c|c|c|c|}
\hline Total & & 2002 & 2006 & 2010 \\
\hline \multirow[t]{9}{*}{ Total } & Rest of the economy & $\begin{array}{l}0.137 \\
(0.000)^{* * *}\end{array}$ & $\begin{array}{c}0.128 \\
(0.000)^{* * *}\end{array}$ & $\begin{array}{c}0.119 \\
(0.000)^{* * *}\end{array}$ \\
\hline & \multirow[t]{2}{*}{ Hospitality } & 0.104 & 0.101 & 0.088 \\
\hline & & $(0.001)^{* * *}$ & $(0.001)^{* * *}$ & $(0.001)^{* * *}$ \\
\hline & \multirow[t]{2}{*}{ Difference } & 0.033 & 0.027 & 0.031 \\
\hline & & $(0.001)^{* * *}$ & $(0.001)^{* * *}$ & $(0.001)^{* * *}$ \\
\hline & \multirow[t]{2}{*}{ Characteristics } & 0.008 & 0.003 & -0.000 \\
\hline & & $(0.000)^{* * *}$ & $(0.000) * * *$ & $(0.000)$ \\
\hline & \multirow[t]{3}{*}{ Coefficients } & 0.025 & 0.024 & 0.031 \\
\hline & & $(0.001)^{* * *}$ & $(0.001)^{* * *}$ & $(0.001)^{* * *}$ \\
\hline$N$ & & 122,432 & 140,241 & 164,648 \\
\hline
\end{tabular}

$* p<0.1 ; * * p<0.05 ; * * * p<0.01$ 


\section{Appendix}

Table A.1.

Descriptives.

$2002 \quad 2006 \quad 2010$

Rest ec. Hospitality Rest ec. Hospitality Rest ec. Hospitality

\begin{tabular}{|c|c|c|c|c|c|c|}
\hline & Rest ec. & Hospitality & Rest ec. & Hospitality & Rest ec. & Hospitality \\
\hline Hourly wage & $\begin{array}{l}8.668 \\
(5.92)\end{array}$ & $\begin{array}{l}6.444 \\
(3.58)\end{array}$ & $\begin{array}{l}9.951 \\
(6.54)\end{array}$ & $\begin{array}{l}7.629 \\
(4.03)\end{array}$ & $\begin{array}{c}12.082 \\
(8.79)\end{array}$ & $\begin{array}{l}8.993 \\
(5.40)\end{array}$ \\
\hline \multirow{2}{*}{ Logarithm of the hourly wage } & 2.015 & 1.787 & 2.158 & 1.951 & 2.342 & 2.109 \\
\hline & $(0.50)$ & $(0.35)$ & $(0.49)$ & $(0.37)$ & $(0.51)$ & $(0.36)$ \\
\hline Male & 0.655 & 0.451 & 0.603 & 0.417 & 0.588 & 0.411 \\
\hline Female & 0.345 & 0.549 & 0.397 & 0.583 & 0.412 & 0.589 \\
\hline Native & 0.970 & 0.920 & 0.934 & 0.818 & 0.936 & 0.814 \\
\hline Immigrant & 0.030 & 0.080 & 0.066 & 0.182 & 0.064 & 0.186 \\
\hline \multirow{2}{*}{ Experience } & 21.727 & 21.968 & 22.420 & 23.180 & 23.189 & 24.945 \\
\hline & (11.74) & $(11.60)$ & (11.94) & $(12.06)$ & $(11.62)$ & $(11.83)$ \\
\hline \multirow{2}{*}{ Years of education } & 9.884 & 8.290 & 10.109 & 8.198 & 10.921 & 8.743 \\
\hline & $(3.76)$ & $(2.83)$ & $(4.14)$ & $(3.45)$ & $(3.90)$ & $(3.09)$ \\
\hline \multirow{2}{*}{ Tenure } & 7.314 & 4.505 & 7.209 & 4.502 & 8.646 & 6.009 \\
\hline & $(9.26)$ & $(7.11)$ & $(9.27)$ & $(7.28)$ & $(9.56)$ & $(7.85)$ \\
\hline Fixed-term contract & 0.271 & 0.272 & 0.290 & 0.265 & 0.221 & 0.208 \\
\hline Permanent contract & 0.729 & 0.728 & 0.710 & 0.735 & 0.779 & 0.792 \\
\hline Part-time & 0.097 & 0.216 & 0.147 & 0.277 & 0.156 & 0.420 \\
\hline Full-time & 0.903 & 0.784 & 0.853 & 0.723 & 0.844 & 0.580 \\
\hline Supervision & 0.259 & 0.257 & 0.179 & 0.205 & 0.189 & 0.213 \\
\hline Non-supervision & 0.741 & 0.743 & 0.821 & 0.795 & 0.811 & 0.787 \\
\hline Skilled occupations & 0.283 & 0.059 & 0.290 & 0.059 & 0.377 & 0.111 \\
\hline Semi-skilled occupations & 0.586 & 0.728 & 0.569 & 0.616 & 0.518 & 0.622 \\
\hline Unskilled occupations & 0.131 & 0.213 & 0.141 & 0.325 & 0.106 & 0.267 \\
\hline Andalucía & 0.096 & 0.090 & 0.095 & 0.093 & 0.100 & 0.131 \\
\hline Aragón & 0.047 & 0.036 & 0.044 & 0.047 & 0.038 & 0.028 \\
\hline Asturias & 0.034 & 0.031 & 0.029 & 0.034 & 0.028 & 0.016 \\
\hline Baleares & 0.027 & 0.097 & 0.025 & 0.085 & 0.026 & 0.115 \\
\hline Canarias & 0.040 & 0.107 & 0.037 & 0.095 & 0.036 & 0.141 \\
\hline Cantabria & 0.018 & 0.021 & 0.020 & 0.027 & 0.022 & 0.019 \\
\hline Castilla-La Mancha & 0.046 & 0.036 & 0.048 & 0.031 & 0.038 & 0.014 \\
\hline Castilla y León & 0.051 & 0.056 & 0.058 & 0.052 & 0.051 & 0.021 \\
\hline Cataluña & 0.166 & 0.127 & 0.158 & 0.108 & 0.182 & 0.161 \\
\hline Comunidad Valenciana & 0.108 & 0.088 & 0.100 & 0.087 & 0.084 & 0.063 \\
\hline Extremadura & 0.024 & 0.030 & 0.025 & 0.026 & 0.021 & 0.007 \\
\hline Galicia & 0.065 & 0.034 & 0.059 & 0.044 & 0.054 & 0.017 \\
\hline Madrid & 0.135 & 0.127 & 0.150 & 0.142 & 0.190 & 0.192 \\
\hline Murcia & 0.038 & 0.033 & 0.042 & 0.036 & 0.029 & 0.011 \\
\hline Navarra & 0.026 & 0.028 & 0.024 & 0.031 & 0.027 & 0.010 \\
\hline País Vasco & 0.059 & 0.039 & 0.066 & 0.041 & 0.057 & 0.037 \\
\hline La Rioja & 0.018 & 0.019 & 0.018 & 0.015 & 0.015 & 0.016 \\
\hline Ceuta and Melilla & 0.001 & 0.000 & 0.001 & 0.005 & 0.002 & 0.003 \\
\hline Size less than 20 & 0.203 & 0.235 & 0.217 & 0.269 & 0.234 & 0.217 \\
\hline Size $20-49$ & 0.255 & 0.272 & 0.233 & 0.261 & 0.119 & 0.109 \\
\hline Size 50-99 & 0.140 & 0.165 & 0.126 & 0.157 & 0.099 & 0.086 \\
\hline Size 100-199 & 0.108 & 0.143 & 0.102 & 0.117 & 0.127 & 0.140 \\
\hline Size $200-499$ & 0.152 & 0.129 & 0.147 & 0.127 & 0.212 & 0.191 \\
\hline Size 500 or more & 0.142 & 0.056 & 0.175 & 0.069 & 0.209 & 0.258 \\
\hline National collective agreement & 0.394 & 0.151 & 0.411 & 0.175 & 0.312 & 0.050 \\
\hline Infra-national collective agreement & 0.496 & 0.834 & 0.507 & 0.808 & 0.378 & 0.885 \\
\hline Firm-level agreement & 0.110 & 0.015 & 0.082 & 0.017 & 0.310 & 0.065 \\
\hline Number of observations & 113,773 & 8,659 & 130,771 & 9,470 & 159,310 & 5,338 \\
\hline
\end{tabular}

Notes: Standard deviation of continuous variables in brackets. 
Table A.2.

Results of the unconditional quantile regressions. Hospitality.

\begin{tabular}{|c|c|c|c|c|c|c|c|c|c|}
\hline & Percentile 10 & $\begin{array}{l}2002 \\
\text { Median }\end{array}$ & Percentile 90 & Percentile 10 & $\begin{array}{l}2006 \\
\text { Median }\end{array}$ & Percentile 90 & Percentile 10 & $\begin{array}{l}2010 \\
\text { Median }\end{array}$ & Percentile 90 \\
\hline Man & $\begin{array}{l}0.021 \\
(0.008)^{* *}\end{array}$ & $\begin{array}{l}0.078 \\
(0.007)^{* * *}\end{array}$ & $\begin{array}{l}0.193 \\
(0.020)^{* * *}\end{array}$ & $\begin{array}{l}0.040 \\
(0.008)^{* * *}\end{array}$ & $\begin{array}{l}0.077 \\
(0.007)^{* * *}\end{array}$ & $\begin{array}{l}0.166 \\
(0.018)^{* * *}\end{array}$ & $\begin{array}{l}0.030 \\
(0.010)^{* * *}\end{array}$ & $\begin{array}{l}0.070 \\
(0.009)^{* * *}\end{array}$ & $\begin{array}{c}0.166 \\
(0.027)^{* * *}\end{array}$ \\
\hline Immigrant & $\begin{array}{l}0.005 \\
(0.014)\end{array}$ & $\begin{array}{l}0.012 \\
(0.012)\end{array}$ & $\begin{array}{l}0.045 \\
(0.029)\end{array}$ & $\begin{array}{l}-0.011 \\
(0.012)\end{array}$ & $\begin{array}{l}-0.011 \\
(0.009)\end{array}$ & $\begin{array}{l}0.017 \\
(0.021)\end{array}$ & $\begin{array}{l}0.016 \\
(0.014)\end{array}$ & $\begin{array}{l}-0.001 \\
(0.012)\end{array}$ & $\begin{array}{l}-0.017 \\
(0.028)\end{array}$ \\
\hline Experience & $\begin{array}{l}0.004 \\
(0.001)^{* * *}\end{array}$ & $\begin{array}{l}0.003 \\
(0.001)^{* *}\end{array}$ & $\begin{array}{l}0.015 \\
(0.003)^{* * *}\end{array}$ & $\begin{array}{l}0.001 \\
(0.001)\end{array}$ & $\begin{array}{l}0.001 \\
(0.001)\end{array}$ & $\begin{array}{l}0.012 \\
(0.003)^{* * *}\end{array}$ & $\begin{array}{l}0.004 \\
(0.002)^{*}\end{array}$ & $\begin{array}{l}0.001 \\
(0.002)\end{array}$ & $\begin{array}{l}0.006 \\
(0.004)\end{array}$ \\
\hline Education & $\begin{array}{l}0.005 \\
(0.002)^{* * *}\end{array}$ & $\begin{array}{l}0.008 \\
(0.001)^{* * *}\end{array}$ & $\begin{array}{l}0.028 \\
(0.005)^{* * *}\end{array}$ & $\begin{array}{l}0.005 \\
(0.001)^{* * *}\end{array}$ & $\begin{array}{l}0.005 \\
(0.001)^{* * *}\end{array}$ & $\begin{array}{l}0.017 \\
(0.003)^{* * *}\end{array}$ & $\begin{array}{l}0.002 \\
(0.002)\end{array}$ & $\begin{array}{l}0.008 \\
(0.002)^{* * *}\end{array}$ & $\begin{array}{c}0.029 \\
(0.005)^{* * *}\end{array}$ \\
\hline Tenure & $\begin{array}{l}0.008 \\
(0.001)^{* * *}\end{array}$ & $\begin{array}{l}0.013 \\
(0.001)^{* * *}\end{array}$ & $\begin{array}{l}0.013 \\
(0.005)^{* * *}\end{array}$ & $\begin{array}{l}0.005 \\
(0.002)^{* * *}\end{array}$ & $\begin{array}{l}0.008 \\
(0.001)^{* * *}\end{array}$ & $\begin{array}{l}0.006 \\
(0.005)\end{array}$ & $\begin{array}{l}0.007 \\
(0.002)^{* * *}\end{array}$ & $\begin{array}{l}0.007 \\
(0.002)^{* * *}\end{array}$ & $\begin{array}{c}0.006 \\
(0.006)\end{array}$ \\
\hline Fixed-term contract & $\begin{array}{l}-0.008 \\
(0.011)\end{array}$ & $\begin{array}{l}-0.025 \\
(0.009)^{* * *}\end{array}$ & $\begin{array}{l}-0.027 \\
(0.019)\end{array}$ & $\begin{array}{l}-0.049 \\
(0.012)^{* * *}\end{array}$ & $\begin{array}{l}-0.045 \\
(0.008)^{* * *}\end{array}$ & $\begin{array}{l}-0.011 \\
(0.018)\end{array}$ & $\begin{array}{l}0.005 \\
(0.015)\end{array}$ & $\begin{array}{l}0.008 \\
(0.012)\end{array}$ & $\begin{array}{c}0.023 \\
(0.031)\end{array}$ \\
\hline Part-time & $\begin{array}{l}-0.057 \\
(0.012)^{* * *}\end{array}$ & $\begin{array}{l}0.001 \\
(0.009)\end{array}$ & $\begin{array}{l}0.057 \\
(0.020)^{* * *}\end{array}$ & $\begin{array}{l}-0.051 \\
(0.011)^{* * *}\end{array}$ & $\begin{array}{l}-0.003 \\
(0.008)\end{array}$ & $\begin{array}{l}0.070 \\
(0.020)^{* * *}\end{array}$ & $\begin{array}{l}-0.070 \\
(0.011)^{* * *}\end{array}$ & $\begin{array}{l}-0.043 \\
(0.009)^{* * *}\end{array}$ & $\begin{array}{c}0.115 \\
(0.026)^{* * *}\end{array}$ \\
\hline Supervision & $\begin{array}{l}0.047 \\
(0.007)^{* * *}\end{array}$ & $\begin{array}{l}0.108 \\
(0.008)^{* * *}\end{array}$ & $\begin{array}{l}0.382 \\
(0.031)^{* * *}\end{array}$ & $\begin{array}{l}0.057 \\
(0.009)^{* * *}\end{array}$ & $\begin{array}{l}0.139 \\
(0.008)^{* * *}\end{array}$ & $\begin{array}{l}0.409 \\
(0.030)^{* * *}\end{array}$ & $\begin{array}{l}0.003 \\
(0.012)\end{array}$ & $\begin{array}{l}0.144 \\
(0.011)^{* * *}\end{array}$ & $\begin{array}{c}0.379 \\
(0.041)^{* * *}\end{array}$ \\
\hline Semi-skilled occupation & $\begin{array}{l}-0.006 \\
(0.012)\end{array}$ & $\begin{array}{l}-0.105 \\
(0.012)^{* * *}\end{array}$ & $\begin{array}{l}-0.759 \\
(0.066)^{* * *}\end{array}$ & $\begin{array}{l}0.006 \\
(0.014)\end{array}$ & $\begin{array}{l}-0.103 \\
(0.012)^{* * *}\end{array}$ & $\begin{array}{l}-0.758 \\
(0.062)^{* * *}\end{array}$ & $\begin{array}{l}-0.036 \\
(0.012)^{* * *}\end{array}$ & $\begin{array}{l}-0.083 \\
(0.013)^{* * *}\end{array}$ & $\begin{array}{r}-0.606 \\
(0.064)^{* * *}\end{array}$ \\
\hline Non-skilled occupation & $\begin{array}{l}-0.033 \\
(0.016)^{* *}\end{array}$ & $\begin{array}{l}-0.190 \\
(0.015)^{* * *}\end{array}$ & $\begin{array}{l}-0.840 \\
(0.068)^{* * *}\end{array}$ & $\begin{array}{l}-0.003 \\
(0.017)\end{array}$ & $\begin{array}{l}-0.126 \\
(0.014)^{* * *}\end{array}$ & $\begin{array}{l}-0.835 \\
(0.063)^{* * *}\end{array}$ & $\begin{array}{l}-0.071 \\
(0.018)^{* * *}\end{array}$ & $\begin{array}{l}-0.138 \\
(0.016)^{* * *}\end{array}$ & $\begin{array}{r}-0.614 \\
(0.066)^{* * *}\end{array}$ \\
\hline Size less than 20 & $\begin{array}{l}-0.006 \\
(0.012)\end{array}$ & $\begin{array}{l}-0.033 \\
(0.009)^{* * *}\end{array}$ & $\begin{array}{l}-0.080 \\
(0.020)^{* * *}\end{array}$ & $\begin{array}{l}-0.049 \\
(0.012)^{* * *}\end{array}$ & $\begin{array}{l}-0.068 \\
(0.009)^{* * *}\end{array}$ & $\begin{array}{l}-0.061 \\
(0.020)^{* * *}\end{array}$ & $\begin{array}{l}-0.037 \\
(0.019)^{* *}\end{array}$ & $\begin{array}{l}-0.051 \\
(0.016)^{* * *}\end{array}$ & $\begin{array}{c}0.041 \\
(0.040)\end{array}$ \\
\hline Size 50 to 99 & $\begin{array}{l}0.038 \\
(0.012)^{* * *}\end{array}$ & $\begin{array}{l}0.052 \\
(0.010)^{* * *}\end{array}$ & $\begin{array}{l}0.147 \\
(0.030)^{* * *}\end{array}$ & $\begin{array}{l}-0.017 \\
(0.013)\end{array}$ & $\begin{array}{l}0.042 \\
(0.010)^{* * *}\end{array}$ & $\begin{array}{l}0.073 \\
(0.030)^{* *}\end{array}$ & $\begin{array}{l}0.005 \\
(0.020)\end{array}$ & $\begin{array}{l}0.007 \\
(0.020)\end{array}$ & $\begin{array}{c}0.038 \\
(0.057)\end{array}$ \\
\hline Size 100 to 199 & $\begin{array}{l}0.032 \\
(0.012)^{* * *}\end{array}$ & $\begin{array}{l}0.058 \\
(0.011)^{* * *}\end{array}$ & $\begin{array}{l}0.191 \\
(0.033)^{* * *}\end{array}$ & $\begin{array}{l}-0.007 \\
(0.013)\end{array}$ & $\begin{array}{l}0.050 \\
(0.012)^{* * *}\end{array}$ & $\begin{array}{l}0.133 \\
(0.036)^{* * *}\end{array}$ & $\begin{array}{l}-0.003 \\
(0.018)\end{array}$ & $\begin{array}{l}0.054 \\
(0.018)^{* * *}\end{array}$ & $\begin{array}{c}0.076 \\
(0.051)\end{array}$ \\
\hline Size 200 to 499 & $\begin{array}{l}0.037 \\
(0.012)^{* * *}\end{array}$ & $\begin{array}{l}0.074 \\
(0.012)^{* * *}\end{array}$ & $\begin{array}{l}0.085 \\
(0.034)^{* *}\end{array}$ & $\begin{array}{l}0.001 \\
(0.013)\end{array}$ & $\begin{array}{l}0.024 \\
(0.012)^{* *}\end{array}$ & $\begin{array}{l}0.052 \\
(0.034)\end{array}$ & $\begin{array}{l}0.006 \\
(0.018)\end{array}$ & $\begin{array}{l}0.051 \\
(0.017)^{* * *}\end{array}$ & $\begin{array}{c}0.037 \\
(0.050)\end{array}$ \\
\hline Size 500 or more & $\begin{array}{l}0.010 \\
(0.019)\end{array}$ & $\begin{array}{l}-0.003 \\
(0.017)\end{array}$ & $\begin{array}{l}0.167 \\
(0.056)^{* * *}\end{array}$ & $\begin{array}{l}0.030 \\
(0.020)\end{array}$ & $\begin{array}{l}0.088 \\
(0.016)^{* * *}\end{array}$ & $\begin{array}{l}0.172 \\
(0.047)^{* * *}\end{array}$ & $\begin{array}{l}-0.027 \\
(0.018)\end{array}$ & $\begin{array}{l}-0.020 \\
(0.017)\end{array}$ & $\begin{array}{l}-0.014 \\
(0.048)\end{array}$ \\
\hline Sect. national agreement & $\begin{array}{l}-0.031 \\
(0.040)\end{array}$ & $\begin{array}{l}-0.088 \\
(0.033)^{* * *}\end{array}$ & $\begin{array}{l}-0.065 \\
(0.100)\end{array}$ & $\begin{array}{l}-0.109 \\
(0.034)^{* * *}\end{array}$ & $\begin{array}{l}-0.166 \\
(0.022)^{* * *}\end{array}$ & $\begin{array}{l}-0.067 \\
(0.083)\end{array}$ & $\begin{array}{l}0.041 \\
(0.040)\end{array}$ & $\begin{array}{l}-0.038 \\
(0.026)\end{array}$ & $\begin{array}{r}-0.320 \\
(0.077)^{* * *}\end{array}$ \\
\hline Sect. infra-national agreement & $\begin{array}{l}0.014 \\
(0.039)\end{array}$ & $\begin{array}{l}-0.073 \\
(0.031)^{* *}\end{array}$ & $\begin{array}{l}-0.023 \\
(0.097)\end{array}$ & $\begin{array}{l}-0.028 \\
(0.033)\end{array}$ & $\begin{array}{l}-0.137 \\
(0.021)^{* * *}\end{array}$ & $\begin{array}{l}-0.058 \\
(0.081)\end{array}$ & $\begin{array}{l}0.146 \\
(0.028)^{* * *}\end{array}$ & $\begin{array}{l}-0.036 \\
(0.020)^{*}\end{array}$ & $\begin{array}{r}-0.297 \\
(0.067)^{* * *}\end{array}$ \\
\hline Intercept & $\begin{array}{l}1.321 \\
(0.052)^{* * *}\end{array}$ & $\begin{array}{l}1.717 \\
(0.044)^{* * *}\end{array}$ & $\begin{array}{l}2.315 \\
(0.140)^{* * *}\end{array}$ & $\begin{array}{l}1.586 \\
(0.047)^{* * *}\end{array}$ & $\begin{array}{l}2.038 \\
(0.034)^{* * *}\end{array}$ & $\begin{array}{l}2.612 \\
(0.123)^{* * *}\end{array}$ & $\begin{array}{l}1.573 \\
(0.052)^{* * *}\end{array}$ & $\begin{array}{l}1.994 \\
(0.041)^{* * *}\end{array}$ & $\begin{array}{c}2.705 \\
(0.131)^{* * *}\end{array}$ \\
\hline$R^{2}$ & 0.14 & 0.26 & 0.21 & 0.10 & 0.24 & 0.20 & 0.10 & 0.25 & 0.21 \\
\hline Observations & 8,659 & 8,659 & 8,659 & 9,470 & 9,470 & 9,470 & 5,338 & 5,338 & 5,338 \\
\hline
\end{tabular}

Table A.3. Results of the unconditional quantile regressions. Rest of the economy. 


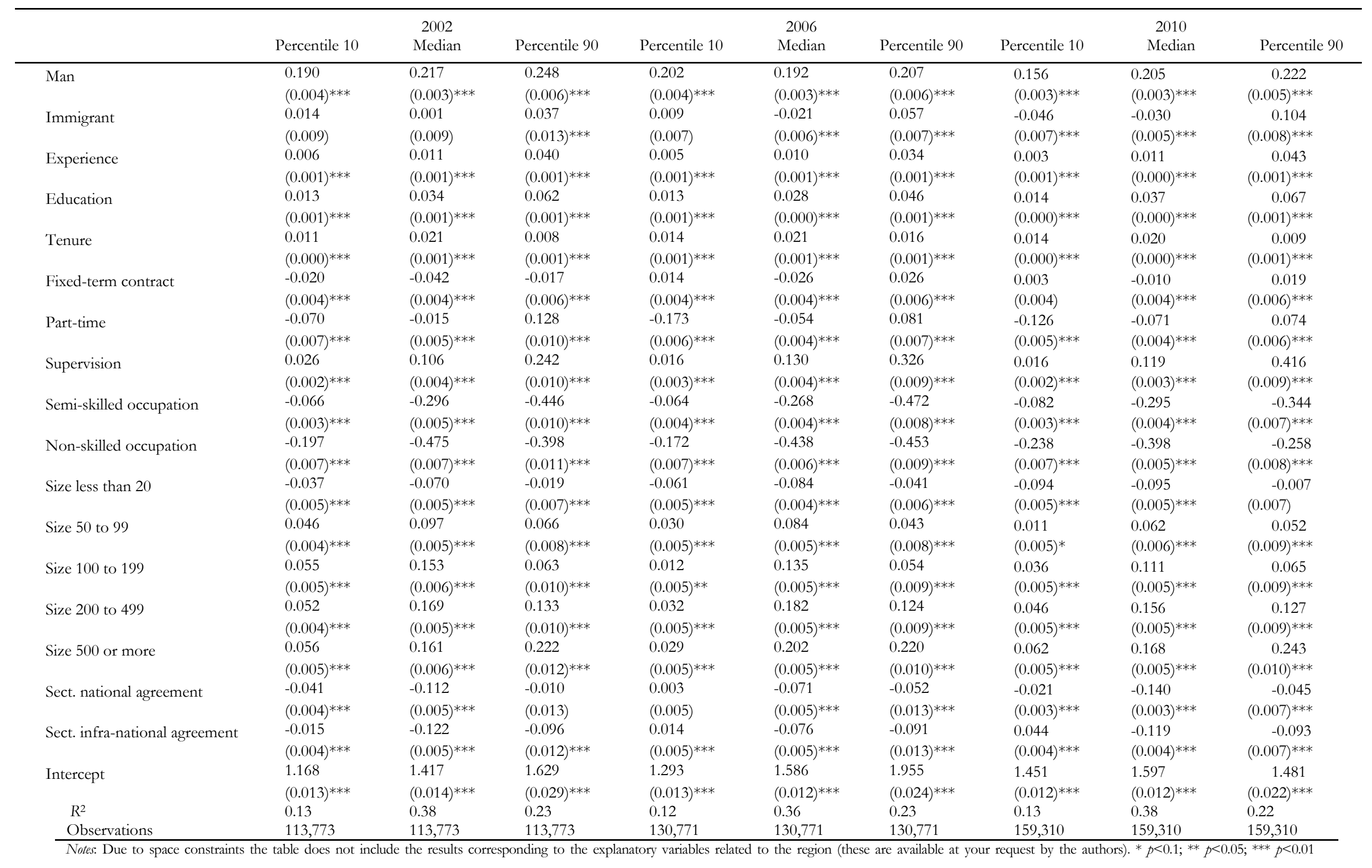


Figure A.1.

Detailed decomposition of the wage gap between the hospitality sector and the rest of the economy. Characteristics component.
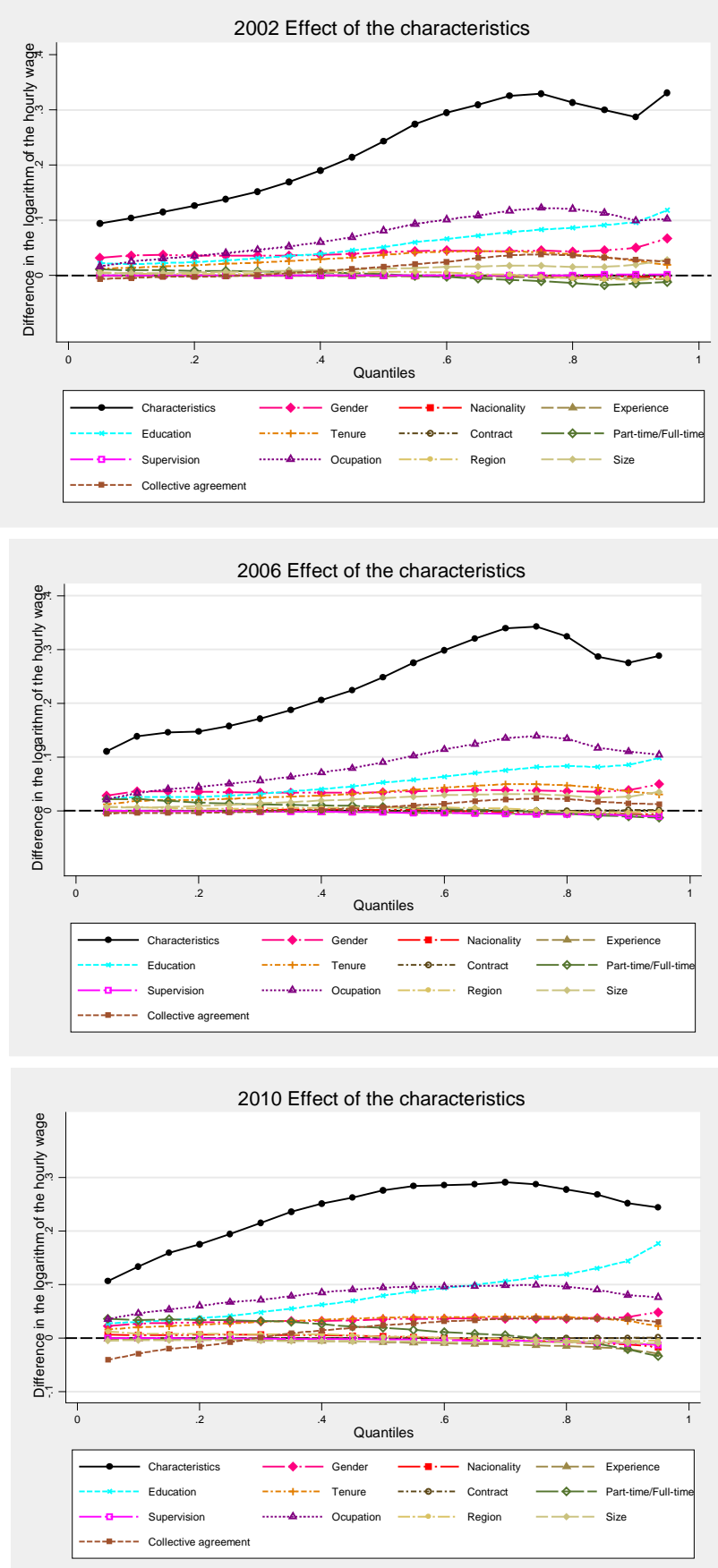